\title{
Environmental constraints on the production and removal of the climatically active gas dimethylsulphide (DMS) and implications for ecosystem modelling
}

\author{
Jacqueline Stefels • Michael Steinke • \\ Suzanne Turner $\cdot$ Gill Malin $\cdot$ Sauveur Belviso
}

Received: 14 June 2006/Accepted: 5 August 2006/Published online: 27 April 2007

(C) Springer Science+Business Media B.V. 2007

\begin{abstract}
Seawater concentrations of the climatecooling, volatile sulphur compound dimethylsulphide (DMS) are the result of numerous production and consumption processes within the marine ecosystem. Due to this complex nature, it is difficult to predict temporal and geographical distribution patterns of DMS concentrations and the inclusion of DMS into global ocean climate models has only been attempted recently. Comparisons between individual model predictions, and ground-truthing exercises revealed that information on the functional
\end{abstract}

J. Stefels $(\bowtie)$

Laboratory of Plant Physiology, University of Groningen, P.O. Box 14, 9750 AA Haren, The Netherlands

e-mail: j.stefels@rug.nl

M. Steinke $\cdot$ S. Turner - G. Malin

Laboratory for Global Marine and Atmospheric

Chemistry, School of Environmental Sciences,

University of East Anglia, Norwich NR4 7TJ, UK

\section{S. Belviso}

Laboratoire des Sciences du Climat et de l'Environnement, UMR CEA-CNRS 1572, CEN/

Saclay, Bât 709, L'Orme des Merisiers, 91191 Gif-sur-

Yvette, France

Present Address:

M. Steinke

Department of Biological Sciences, University of

Essex, Wivenhoe Park, Colchester CO4 3SQ, UK relationships between physical and chemical ecosystem parameters, biological productivity and the production and consumption of DMS and its precursor dimethylsulphoniopropionate (DMSP) is necessary to further refine future climate models. In this review an attempt is made to quantify these functional relationships. The description of processes includes: (1) parameters controlling DMSP production such as species composition and abiotic factors; (2) the conversion of DMSP to DMS by algal and bacterial enzymes; (3) the fate of DMSPsulphur due to, e.g., grazing, microbial consumption and sedimentation and (4) factors controlling DMS removal from the water column such as microbial consumption, photo-oxidation and emission to the atmosphere. We recommend the differentiation of six phytoplankton groups for inclusion in future models: eukaryotic and prokaryotic picoplankton, diatoms, dinoflagellates, and other phytoflagellates with and without DMSP-lyase activity. These functional groups are characterised by their cell size, DMSP content, DMSP-lyase activity and interactions with herbivorous grazers. In this review, emphasis is given to ecosystems dominated by the globally relevant haptophytes Emiliania huxleyi and Phaeocystis sp., which are important DMS and DMSP producers.

Keywords Climate modelling · DMS - DMSP . Emiliania huxleyi · Functional groups .

Phaeocystis 


\section{Introduction}

Dimethylsulphide (DMS) is a semivolatile organic sulphur compound that accounts for $50-60 \%$ of the total natural reduced sulphur flux to the atmosphere, including emissions from volcanoes and from vegetation (Andreae 1990; Bates et al. 1992; Spiro et al. 1992). By providing $95 \%$ of the flux to the atmosphere, the oceans are the main source for DMS, with estimates of its emission ranging between 15 and $33 \mathrm{Tg} \mathrm{S} \mathrm{y}^{-1}$ (Kettle and Andreae 2000). In the late 1980s, the hypothesis that DMS is involved in the biological regulation of global climate was put forward (Bates et al. 1987; Charlson et al. 1987). It is, however, only recently that DMS has been incorporated in global climate models (e.g., Aumont et al. 2002; Bopp et al. 2003, 2004; Gabric et al. 2004; Kettle and Andreae 2000; Simo and Dachs 2002). After emission to the atmosphere, this volatile sulphur compound is oxidised to sulphur dioxide $\left(\mathrm{SO}_{2}\right)$ and other products. From $\mathrm{SO}_{2}$, non-sea-salt (nss) sulphate is produced, which can form sulphate $\left(\mathrm{SO}_{4}^{2-}\right)$ particles that act as condensation nuclei for water vapour. These nuclei affect the radiative properties of the atmosphere and clouds, with implications for climate. Higher numbers of condensation nuclei will deflect more incoming solar radiation back into space and thereby reduce the temperature on earth. The hypothesis that this process may modulate the greenhouse effect of increased anthropogenic $\mathrm{CO}_{2}$ input to the atmosphere, was indirectly supported by the modelling results of the effect of anthropogenic $\mathrm{SO}_{2}$ input to the atmosphere (Andreae et al. 2005; Mitchell et al. 1995). Although this study gave a rough indication of the counteracting effects of atmospheric $\mathrm{SO}_{2}$ and $\mathrm{CO}_{2}$, a quantitative understanding of all sources and sinks of atmospheric aerosols is still lacking (Andreae and Crutzen 1997).

Currently, anthropogenic $\mathrm{SO}_{2}$ production exceeds natural $\mathrm{SO}_{2}$ production by a factor of 3 (Bates et al. 1992), but the impact of the former on aerosol production is largely confined to industrialised areas of the Northern Hemisphere. The oceans, on the other hand, cover approximately $70 \%$ of the Earth's surface and much of this area is remote from man-made atmospheric contaminants. Consequently, the exchange of marine DMS is of high regional importance and may affect climate globally. Since the publication of a global inventory of DMS data by
Kettle and co-authors (Kettle et al. 1999), it has become possible to include DMS in global climate models. Indeed, recent model calculations have shown that in the Southern Hemisphere, where anthropogenic sulphate emission is low, DMS plays a major role in the production of atmospheric nsssulphate (Gondwe et al. 2003). Gondwe et al. calculated that the contribution of DMS to the total (global) atmospheric nss-sulphate burden is $18 \%$ and that it shows significant regional and temporal differences; e.g., in the Southern Hemisphere its annual contribution is $43 \%$ and over the Southern Ocean it is in excess of $80 \%$ during summer.

In one of the early attempts to add DMS in a global ocean climate model, Bopp et al. (2003) showed that a doubling of the atmospheric $\mathrm{CO}_{2}$ concentration resulted in a reduction of the DMS flux at low latitudes and in enrichment at mid-latitudes. Thus, depending on the sign of the chance in DMS flux, the subsequent climate forcing by sulphur products could either alleviate or amplify the greenhouse effect (Bopp et al. 2004). The inclusion of DMS in the model was achieved by coupling the production of dimethylsulphoniopropionate (DMSP) and its conversion to DMS with the trophic status of the ecosystem, which in turn was based on the silica ratio, defined as the local simulated production of biogenic silica relative to the maximum production and is related to the proliferation of diatoms. It is computed from local silica concentrations and a variable Si:C ratio, which depends on the silica concentration. Although simplistic in its ecological approach, this study showed that an increased $\mathrm{CO}_{2}$ concentration doesnot necessarily result in increased DMS production that may counterbalance the greenhouse effect, as suggested by the Charlson-LovelockAndreae-Warren (CLAW) hypothesis (Charlson et al. 1987). Clearly, an improved understanding of the biological processes is necessary to address the role of DMS in climate feedback mechanisms.

The production of DMS is almost exclusively through biogenic processes and shows strong seasonal and latitudinal variation (Kettle et al. 1999). DMS mainly results from the enzymatic cleavage of DMSP, a compound that is produced in several groups of marine phytoplankton. A complex network of production and consumption pathways of both DMSP and DMS involves most of the microbial food web (Fig. 1) and determines the concentration of 
DMS in surface water and consequently its flux to the atmosphere (Malin and Kirst 1997). Physical and chemical ecosystem parameters all affect this network, potentially resulting in dramatic shifts in the DMS flux to the atmosphere. Although our knowledge on the qualitative aspects of the marine sulphur cycle has improved considerably during the past two decades, it is still difficult to quantify the effects of controlling factors on the various pathways.
Ecosystem modelling provides a tool for investigating how the DMS concentration and subsequently its flux to the atmosphere are regulated and what the most critical processes are. In a recent review on DMS and DMSP ecosystem models, Vezina (2004) concluded that although all current models will greatly benefit from improvements to the underlying ecosystem model, the quantitative understanding of the processes that drive variations in DMS and DMSP

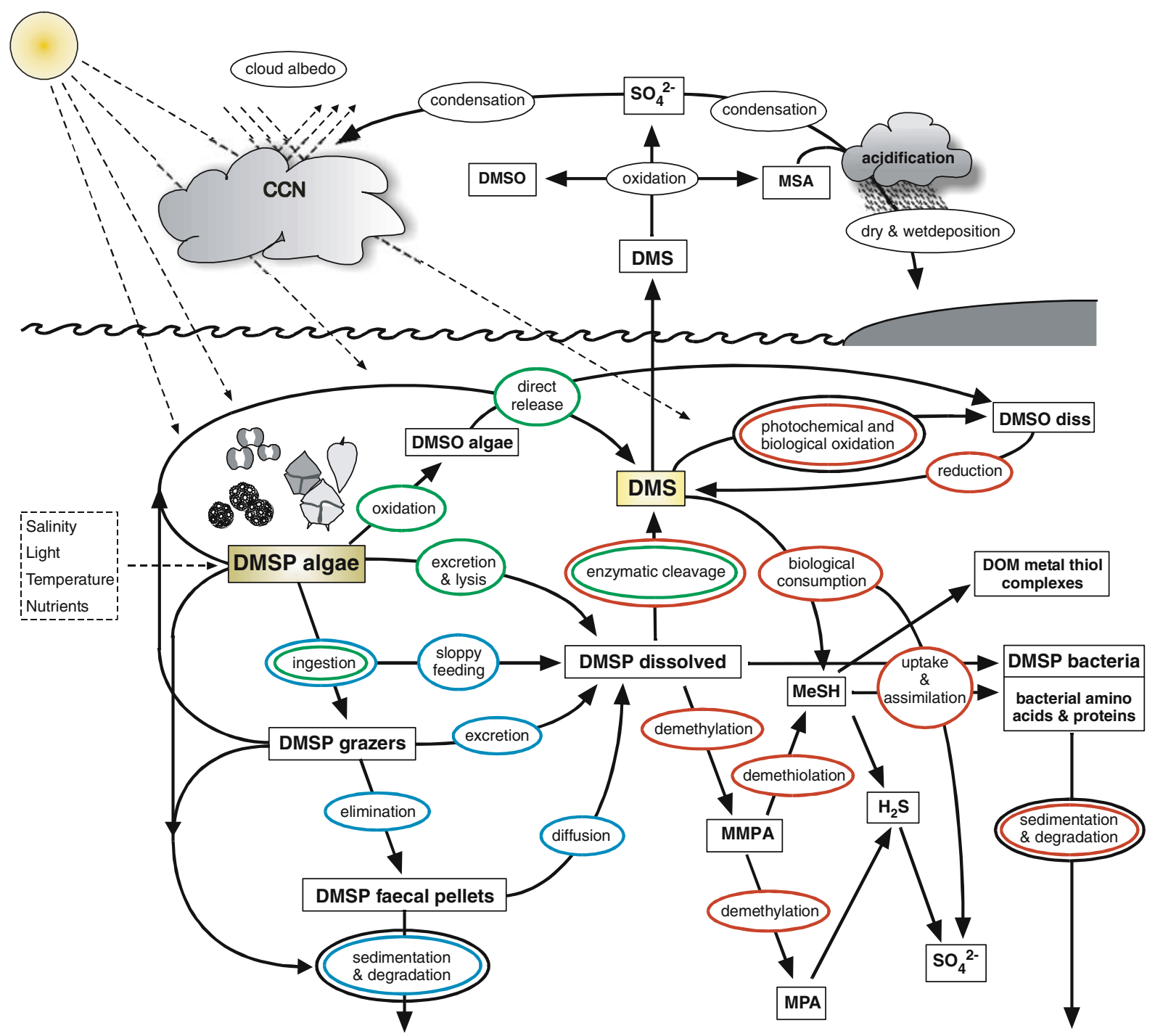

Fig. 1 Schematic representation of the processes and pools involved in the marine biogeochemical cycling of DMSP and DMS. Dominant role of functional groups in the different processes is indicated by coloured ellipses: green, phytoplankton; blue, zooplankton; red, bacteria; black, abiotic factors.
CCN, cloud-condensation nuclei; DOM, dissolved organic material; DMSO, dimethyl sulphoxide; MeSH, methanethiol; MPA, mercaptopropionate; MMPA, methylmercaptopropionate; MSA, methanesulphonic acid 
[DMS(P)] quotas and microbial yields is still too limited. Such insights are needed to inform laboratory and field studies and aid us in the development of more robust $\mathrm{DMS}(\mathrm{P})$-modules within ecosystem models. During the past decade, many excellent reviews have been written on several aspects of the marine sulphur cycle. One of the emerging pictures is that this cycle is not only of interest for global climate, but that DMS and DMSP are compounds which are central to the microbial food web in their own right. The purpose of this review is not so much to reiterate these reviews, but rather to use pertinent information from them in an attempt to assist the development of parameterisations for DMSP and DMS modelling.

In this review, much attention has been given to two specific algal haptophyte taxa: Phaeocystis sp. and Emiliania huxleyi. These algae are well known as prolific producers of DMS and DMSP and their blooms can cover extensive areas in neritic and open ocean waters, respectively. Due to an increased interest to define the phytoplankton realm in models in more detail, we have tried to find unifying processes, but most published information is from Phaeocystis and $E$. huxleyi. Since our main goal is to provide an understanding of the complexity of the system, we have chosen to describe the various processes independently, even though this may have resulted in some repetition of observations. The level of detail may not be equal throughout the paper, but is a reflection of the current state of knowledge, our judgment of the potential impact of a specific process on the marine sulphur cycle and the assignment of different processes and functional groups in recent (complex) ecosystem models (e.g., Archer et al. 2004). We have tried to be as concise as possible, without losing information necessary for a holistic description. In order to evaluate the relative importance of individual pathways, we have provided the reader with an educated guess of the quantitative aspects, whenever possible. Obviously, when describing the different processes in detail, one comes across many gaps in knowledge. We have therefore taken the opportunity to highlight these gaps and make recommendations for future research.

\section{Factors controlling DMSP production}

A direct coupling of DMSP production with primary production would be ideal for modelling. However, there is no straightforward relationship since DMSP production is confined to a limited number of algal taxa. A further complicating factor is that the physiological conditions of the algal cells affect DMSP production. As a result, there is no definitive global relationship between algal biomass parameters such as chlorophyll- $a$ and algal DMSP. Many ecosystem models are expressed in pools of carbon or nitrogen, whereas many global climate models are more often expressed in units of carbon. These models would benefit from conversion factors to describe the particulate DMSP pool, hence we choose to estimate DMSP:C ratios (on a molar basis) from literature data whenever possible.

\section{Species composition}

From an ecosystem perspective, species composition is the factor that affects community-DMSP production the most. Keller et al. (1989) made an extensive inventory of the DMSP content of 123 clones of marine phytoplankton, analysed during mid-exponential growth in nutrient replete media, and concluded that the major production of DMSP is found in a limited number of species, which mainly belong to the classes of Haptophyceae (=Prymnesiophyceae) and Dinophyceae (dinoflagellates). However, some members of the Chrysophyceae and Bacillariophyceae (diatoms) can also produce significant amounts of DMSP. In order to use this knowledge in models, we have recalculated published data of cellular DMSP concentrations to provide DMSP-to-carbon (DMSP:C) ratios, that can be used to estimate DMSP production in blooms of different taxonomic groups (Table 1). In addition, we have provided DMSP-to-chlorophyll-a (DMSP:chl- $a$ ) ratios, since several global models use satellite-derived chlorophyll- $a$ data multiplied with a trophic status factor, as a proxy for particulate DMSP (Anderson et al. 2001; Aumont et al. 2002; Bopp et al. 2003; Simo and Dachs 2002). The carbon-to-chlorophyll- $a$ conversion factor we used for this calculation $(60 \mathrm{~g} / \mathrm{g})$ is typical for cultures that grow under nutrient-replete conditions and saturating light intensities (Geider 1987). Variations in abiotic factors in the field will, however, have a strong impact on this ratio and, as will be discussed in the following sections, on the DMSP:C and DMSP:chl- $a$ ratios. 
Table 1 Mean DMSP:C ratios, proportion of cell carbon composed of DMSP and DMSP:chlorophyll- $a$ ratios in species groups, with the standard deviation in brackets. Data are recalculated from published data. Carbon per cell was calculated from cell volumes, according to the formula given by

\begin{tabular}{lllll}
\hline Species group & DMSP:C (mol:mol) & Proportion DMSP-carbon & DMSP:chl- $a$ (mmol:g) & Data from \\
\hline Diatoms $(n=22)$ & $0.00086(0.00126)$ & $0.0043(0.0063)$ & $4(6)$ & 2 \\
Chrysophytes $(n=6)$ & $0.019(0.015)$ & $0.094(0.075)$ & $94(75)$ & 2 \\
Dinoflagellates $(n=32)$ & $0.022(0.032)$ & $0.111(0.158)$ & $111(168)$ & $2,3,5$ \\
Prasinophytes $(n=18)$ & $0.005(0.007)$ & $0.025(0.034)$ & $25(34)$ & 1,2 \\
Haptophytes $(n=32)$ & $0.011(0.007)$ & $0.053(0.037)$ & $52(37)$ & $1,2,3,4$ \\
$\begin{array}{l}\text { Prochlorophytes/Cyanophytes } \\
\quad(n=17)\end{array}$ & $0.0000015(0.000004)$ & $0.000008(0.00002)$ & $0.008(0.02)$ & 1,2 \\
\hline
\end{tabular}

Menden-Deuer and Lessard (2000): diatoms: pgC/ cell $=0.288 \times$ cell volume $\left(\mu^{3}\right)^{0.811} ;$ all other algae: $\mathrm{pgC} /$ cell $=0.216 \times$ cell volume $\left(\mu \mathrm{m}^{3}\right)^{0.939}$. Chlorophyll- $a$ per cell was calculated assuming a C:chl- $a$ ratio of $60 \mathrm{~g} / \mathrm{g}$ (see comments in the text)

1. Corn et al. 1996; 2. Keller et al. 1989; 3. Niki et al. 2000; 4. Stefels and van Leeuwe 1998; 5. Wolfe et al. 2002

As is evident from the standard deviations in Table 1 , the variability within the groups is high. In fact, the haptophytes are the only group where all the species tested were observed to produce DMSP. In all other groups, one or several clones did not produce DMSP. Of the groups depicted in Table 1, the prochlorophytes/cyanophytes and diatoms produced the least DMSP. Some exceptions have been observed, but these are not usually found in open ocean areas, but rather at the fringes: in estuaries (e.g., Melosira nummuloides in Keller et al. 1989), in ice algal communities (Baumann et al. 1994; Kirst et al. 1991; Levasseur et al. 1994) and in benthic microbial mats (van Bergeijk et al. 2002). Such data have been excluded from the calculations summarised in Table 1.

The nano/picoplankton are a very diverse group of species that belong to several taxonomic groups and, hence, vary considerably in their DMSP production. For instance, almost all cyanophytes (e.g., Synechococcus species, Trichodesmium), prochlorophytes and cryptophytes tested did not produce DMSP, whereas other species that belong to the chrysophytes and prasinophytes do produce DMSP (Table 1). There are only a few field studies that report on the production of DMSP in picophytoplankton $(<2 \mu \mathrm{m}$ diameter $)$. Corn et al. (1996) showed that picoplankton can contribute up to $25 \%$ of depth-integrated total DMSP in oligotrophic waters of the subtropical Atlantic. Within this fraction, the picoeukaryotes were the main DMSP producers, whereas the prokaryotes contributed less than $1 \%$ of picoplanktonic DMSP.
In contrast, Wilson et al. (1998) investigated DMSP and DMS production in mesocosm enclosures and suggested that Synechococcus can be a significant producer of DMSP under nutrient-replete conditions.

Another aspect of the contribution of different species to global DMSP production is related to their ability to form blooms. Although Table 1 shows that the haptophytes do not have unusually high concentrations of DMSP per cell, the ability of Phaeocystis sp. and Emiliania huxleyi to dominate phytoplankton biomass during the formation of extensive coastal and oceanic blooms can result in elevated levels of DMS(P) (Table 2). These species therefore have received a great deal of research attention. Phaeocystis particularly is known to form almost monospecific spring blooms. Within such blooms, DMSP production is constrained by abiotic factors that affect cell physiology and the ability to produce and retain DMS(P). This topic is explored in the next section.

Physiological condition

The effect of abiotic parameters (light, nutrients, temperature and salinity) on the physiological condition of algal cells and subsequently on the production of DMSP, has been reviewed by Stefels (2000). DMSP is a multifunctional compound and there is no doubt that it has a role as a compatible solute in cell metabolism, but the regulation of its internal concentration is still unresolved. Because many abiotic parameters appear to have an effect to some extent, Stefels (2000) hypothesised that the production of 
Table 2 DMS, dissolved DMSP (DMSP ${ }_{d}$ ) and particulate DMSP $\left(\right.$ DMSP $\left._{\mathrm{p}}\right)$ concentrations and ratios to carbon and chlorophyll- $a$ in blooms of Phaeocystis sp. and Emiliania huxleyi; within brackets are mean concentrations over the period of observation. When available, contribution to the bloom composition is given. See for a discussion on artificially elevated $\mathrm{DMSP}_{\mathrm{d}}$ concentrations the introductory paragraphs of the section 'Mechanisms of release to the dissolved fraction' and Kiene and Slezak (2006)

\begin{tabular}{|c|c|c|c|c|c|c|c|}
\hline Area & $\begin{array}{l}\text { DMS } \\
(\mathrm{nM})\end{array}$ & $\begin{array}{l}\operatorname{DMSP}_{d} \\
(\mathrm{nM})\end{array}$ & $\begin{array}{l}\operatorname{DMSP}_{\mathrm{p}} \\
(\mathrm{nM})\end{array}$ & $\begin{array}{l}\text { DMSP:C } \\
(\mathrm{mol} / \mathrm{mol})\end{array}$ & $\begin{array}{l}\text { DMSP:chla } \\
(\mathrm{mmol} / \mathrm{g})\end{array}$ & $\begin{array}{l}\text { Period of } \\
\text { observation }\end{array}$ & $\begin{array}{l}\text { Data and } \\
\text { comments }\end{array}$ \\
\hline \multicolumn{8}{|l|}{ Phaeocystis } \\
\hline S. Ocean-Davis Station & & & $20-290$ & & & 2 months & 1 \\
\hline S. Ocean-Davis station & & & $94-590$ & & & 1 month & 2 \\
\hline S. Ocean-Ross Sea & $20-110$ & & & & $15^{*}$ & Transect & 3 \\
\hline \multirow[t]{2}{*}{ S. Ocean-Bellingshausen Sea } & & $8-300(77)$ & & & & 1 month & 4 \\
\hline & 27 & & & $0.03 *$ & $18 *$ & Single obs. & 5 \\
\hline Bering Sea & $3-19$ & & & & & 3 days & 6 \\
\hline Barents Sea-“station II" & $9 *$ & $40 *$ & $30 *$ & 0.004 & $17 *$ & Transect & 7 \\
\hline N. Norway-Ullsfjord & $5-41(17)$ & & $25-213(90)$ & 0.006 & 31 & 15 days & 8 \\
\hline NE Atlantic_-Faerøe & $20-85$ & & $20-220$ & $0.02 *$ & $50 *$ & Transect & 9 \\
\hline West English Channel & 24 & & & & & Single obs. & 10 \\
\hline S. North Sea & $3-48(25)$ & & & & 43 & 1 month & 11 \\
\hline S. North Sea-coastal zone & $7-47$ & $6-22$ & $110-470$ & 0.004 & 15 & 1 month & 12 \\
\hline \multirow[t]{2}{*}{ Wadden Sea inlet } & $8-18$ & $20-60$ & $100-1,500$ & & 22 & 1 month & 13 \\
\hline & $2-40$ & $3-35$ & $200-1,650$ & & & 1 month & 14 \\
\hline \multicolumn{8}{|l|}{ Emiliania huxleyi } \\
\hline UK nearshore waters & $1-9$ & & & & & Periodic & 15 \\
\hline Northeast Atlantic & $3-51 *$ & & $85-285$ & 0.02 & $50-140$ & Transect & 16 \\
\hline Northeast Atlantic & $2-16^{\#}$ & & & & & Transect & 17 \\
\hline
\end{tabular}

DMSP might also serve as an overflow mechanism for excess reduced sulphur under conditions of unbalanced growth, when carbon and nitrogen flows are out of tune. The continued production and possible loss of DMSP would serve as a sink for excess carbon and at the same time regenerate intracellular nitrogen from methionine, which can then be used for synthesis of other amino acids. Although such a mechanism seems wasteful, the benefits are the continuation of the metabolic machinery. In this respect, it is comparable to the commonly observed exudation of carbohydrates by cells at high light and low nutrient concentrations. If indeed DMSP production is connected to overflow metabolism, this requires that DMSP is mainly located in the cytosol and that the intracellular equilibrium concentration is regulated by its degradation or loss from the cell rather than by its production. Transport of DMSP out of the cell would then be facilitated by the extracellular cleavage of DMSP (see also 'Maintenance of intracellular DMSP concentration: algal DMSP-lyase activity'). Although this hypothesis can explain many of the observed changes in DMSP content presented in the literature, direct evidence is still lacking.

Another hypothesis on the physiological function of DMSP was presented by Sunda et al. (2002). It suggests that DMSP and its breakdown products DMS, acrylate, dimethylsulphoxide (DMSO) and methane sulphinic acid (MSNA) together form a cascade of radical scavengers that may serve as an efficient anti-oxidant system that would need to be regulated in part by the enzymatic cleavage of DMSP. If true, one would expect the production of DMSP and its enzymatic cleavage to take place in the chloroplast, where most reactive oxygen species (ROS) are produced. This indeed seems to be the case with respect to the production of DMSP in 
Table 2 Continued

\begin{tabular}{|c|c|c|c|c|c|c|c|}
\hline Area & $\begin{array}{l}\text { DMS } \\
(\mathrm{nM})\end{array}$ & $\begin{array}{l}\mathrm{DMSP}_{\mathrm{d}} \\
(\mathrm{nM})\end{array}$ & $\begin{array}{l}\operatorname{DMSP}_{p} \\
(\mathrm{nM})\end{array}$ & $\begin{array}{l}\text { DMSP:C } \\
(\mathrm{mol} / \mathrm{mol})\end{array}$ & $\begin{array}{l}\text { DMSP:chla } \\
(\mathrm{mmol} / \mathrm{g})\end{array}$ & $\begin{array}{l}\text { Period of } \\
\text { observation }\end{array}$ & $\begin{array}{l}\text { Data and } \\
\text { comments }\end{array}$ \\
\hline Northeast Atlantic & $4-8$ & & $29-52$ & & $44-112$ & 5 days & 18 \\
\hline Northern North Sea & $3 \pm 0.6$ & $7.2 \pm 3.9$ & $60.9 \pm 19.9$ & & $100 \pm 20.2$ & 6 days & 19 \\
\hline Gulf of Maine & $0.8-8$ & $60-175$ & $60-260$ & & & Single profile & 20 \\
\hline
\end{tabular}

1. Gibson et al. 1990. Original data published as DMS concentrations, but due to the use of $\mathrm{HgCl}_{2}$, most probably an estimation of total DMS + DMSP (see also Curran et al. 1998)

2. Yang et al. (1994): data as for Gibson et al. (1990)

3. DiTullio and Smith 1995. Data from samples with 19'-hexanoyloxyfucoxanthin as the dominant pigment. Calculated from DMSP $\mathrm{p}^{-}$ data plus $11 \%$ of the DMS-data; the latter was estimated to be the methodological bias due to diluting and not-filtering the samples

4. Crocker et al. 1995. Data as for Gibson et al. (1990), but only dissolved DMS + DMSP

5. Turner et al. 1995

6. Barnard et al. 1984. Mean of samples in which Phaeocystis makes up $>25 \%$ of cell density

7. Matrai and Vernet 1997. Mean of samples in which Phaeocystis makes up $43 \%$ of phytoplankton-C

8. Data from April 1997 field campaign of the EU-funded ESCAPE project: Belviso et al. 2006 (DMS and DMSP data) and Stefels (POC and chlorophyll data). Ratios are from the Phaeocystis maximum on April 25

9. Malin et al. 1993

10. Holligan et al. 1987

11. Liss et al. 1994 and Turner et al. 1996

12. Unpublished data from April 1998 field campaign of the EU-funded ESCAPE-project: Belviso (DMS and DMSP data) and Stefels (POC and chlorophyll data). Ratio's are derived from regression coefficients of the respective parameters. Carbon represents phytoplankton carbon as derived from the regression of POC versus chlorophyll- $a$

13. Kwint and Kramer 1996

14. van Duyl et al. 1998

15. Turner et al. 1988. Samples with $>20 \%$ coccolithophores; winter and summer 1985

16. Malin et al. 1993. June-July 1987. Samples with $>50 \%$ of total carbon biomass as coccolithophores

17. Holligan et al. 1993. E. huxleyi bloom, June 1991

18. Jickells et al. unpublished data from ACSOE cruise in the NE Atlantic, June 1998 (eddy—Lagrangian), with E. huxleyi dominating

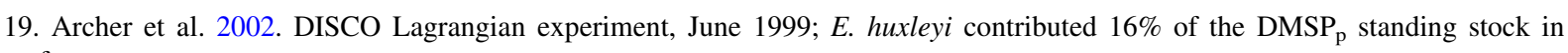
surface waters

20. Matrai and Keller 1993. Centre of an E. huxleyi bloom, July 1990; data range in top 10 m of one depth profile

* Estimated from published figures

\# Surface concentrations along a transect at $20^{\circ} \mathrm{W}$

higher plants (Trossat et al. 1996), but there is no conclusive evidence for this in marine algae, which use a different biochemical pathway for DMSP production (Gage et al. 1997; Summers et al. 1998). Another complicating factor is that with the common techniques for $\operatorname{DMS}(\mathrm{P})$ analysis it is impossible to measure the fluxes through this cascade of compounds. Sunda and co-workers suggested the anti-oxidant hypothesis on the basis of elevated concentrations of intracellular DMSP under stress conditions. In the process of radical scavenging, however, DMSP would be converted into one of its breakdown products. Therefore, a loss of DMSP would be expected, unless the stress reaction results in increased de novo synthesis (up-regulation) of DMSP. Only in those cases, a subsequent overshoot production may lead to increased intracellular concentrations of DMSP and/or one of the downstream products. A method for the measurement of de novo synthesis of DMSP is clearly warranted. 
Since unbalanced growth and the production of ROS often co-occur under high irradiance and/or nutrient-limited conditions, it is difficult to test the two hypotheses individually without detailed investigation of the physiological condition of the cells and fluxes through the relevant biochemical pathways. Moreover, the two hypotheses do not necessarily need to be mutually exclusive, since a function in oxidative stress management does not exclude additional functions in cell metabolism. However, for a better understanding, one should be aware of the fundamental differences in operating principles and value the published data accordingly. Here, we present only an update of the current knowledge and quantify the relationships whenever possible.

\section{Salinity}

There is little doubt that an increase in salinity will result in an increase of the equilibrium concentration of intracellular DMSP, but an active up- or down regulation of its concentration upon short-term salinity changes (minutes to hours) has not been observed (reviewed by Stefels 2000). Indeed, phytoplankton from high-salinity environments such as

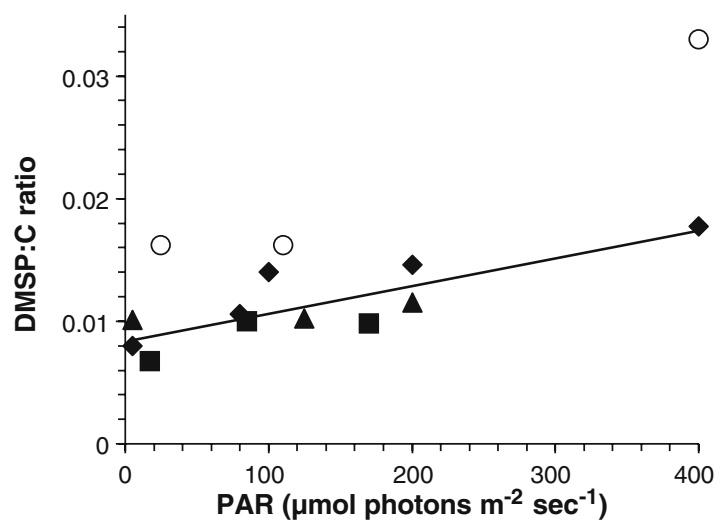

Fig. 2 Effect of irradiance on the cellular DMSP:C-ratio (mol:mol) in Emiliania huxleyi (closed symbols). Data are recalculated from: Slezak and Herndl (2003) (diamonds); Keller and Korjeff-Bellows (1996) (squares); van Rijssel and Buma (2002) and van Rijssel and Gieskes (2002) (triangles). For comparison, data from experiments with Phaocystis antarctica are included (open symbols; Stefels and van Leeuwe 1998; Stefels unpublished). Equation of the linear regression fit (E. huxleyi data only): DMSP:C $=0.00002 \times \mathrm{PAR}+0.0084$ $\left(r^{2}=0.693\right)$ coastal rock pools, hypersaline lakes or sea-ice pore waters are known to accumulate relatively high concentrations of DMSP. In Phaeocystis cultures, an increase of salinity resulted in an exponential increase of intracellular DMSP (Stefels 2000). Therefore, salinity effects need to be taken into account when modelling DMSP production in extreme environments, e.g. when modelling the production of DMSP in sea ice.

\section{Light}

Most experiments on the effect of light on DMSP production by algae have been carried out with Emiliania huxleyi, a species that is unusual in its ability to grow at very high light $\left(>1,000 \mu \mathrm{mol} \mathrm{m} \mathrm{m}^{-2} \mathrm{~s}^{-1}\right.$ ) intensities (Paasche 2001). In order to make the data from the various publications comparable, we have converted intracellular DMSP quota to DMSP:C ratios. From these data, a good correlation between increasing DMSP:C-ratio

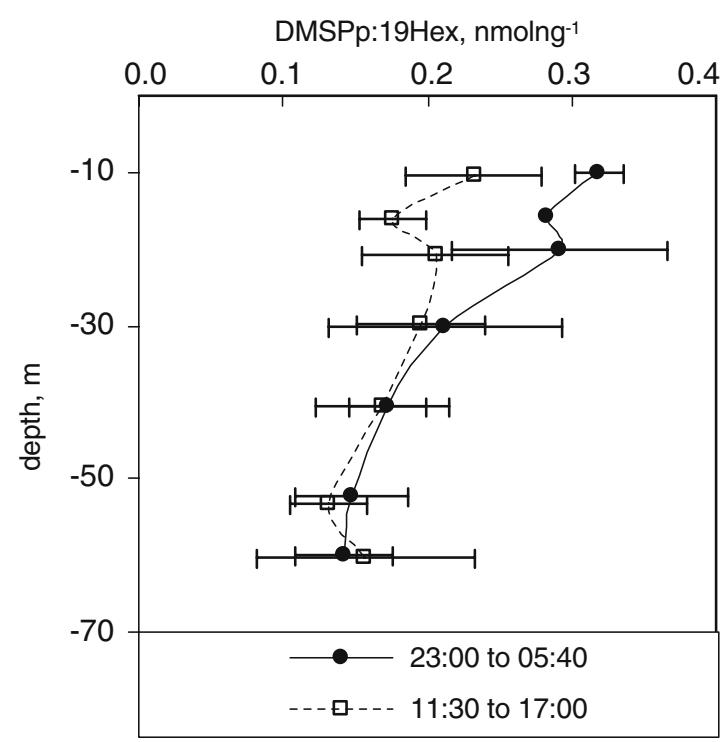

Fig. 3 DMSP $\mathrm{D}_{\mathrm{p}}$ : 19'-hexanoyloxyfucoxanthin $\left(19^{\prime} \mathrm{Hex}\right)$ ratios with depth in the Southern Ocean during light and dark periods. Daylight hours (open symbols), night hours (filled symbols). The data were collected over an 18-day period during which daylight and dark profiles were evenly distributed and the mixed layer depths were between $50 \mathrm{~m}$ and $100 \mathrm{~m}$. The data are binned by depth and shown as averages with range bars of one standard deviation. There are 4-10 data values in each average except for the single dark $15 \mathrm{~m}$ depth and the average depth of the $1 \%$ light level was $55 \mathrm{~m}$ 
and increasing irradiance can be observed (Fig. 2). For comparison, data for Phaeocystis antarctica are included in the figure. A comparable increase with irradiance can be observed, but with an overall higher offset. This offset might be the result of additional temperature effects.

Getting information from field data on the controls on cellular DMSP is not straightforward but there is some evidence from a Lagrangian experiment in the Southern Ocean, which tends to suggest that light is an important factor at the daily scale (Fig. 3; S. Turner and I. Peeken, unpublished data). Figure 3 shows vertical profiles of $\mathrm{DMSP}_{\mathrm{p}}$, normalised to $19^{\prime}$ hexanoyloxyfucoxanthin $\left(19^{\prime} \mathrm{Hex}\right)$, an accessory pigment which is indicative of Prymnesiophytes. Since the changes in the ratios are dominated by variation in DMSP, the results suggest that there is a diel cycle, in which $\mathrm{DMSP}_{\mathrm{p}}$ is consumed during the day. This may be supportive of an antioxidant function, but also shows that short-term effects can be opposite to longterm effects as presented by Sunda et al. (2002) and as shown in Fig. 2. Clearly, better methods are warranted to measure fluxes through the $\mathrm{DMSP}_{\mathrm{p}}$ pool in field samples.

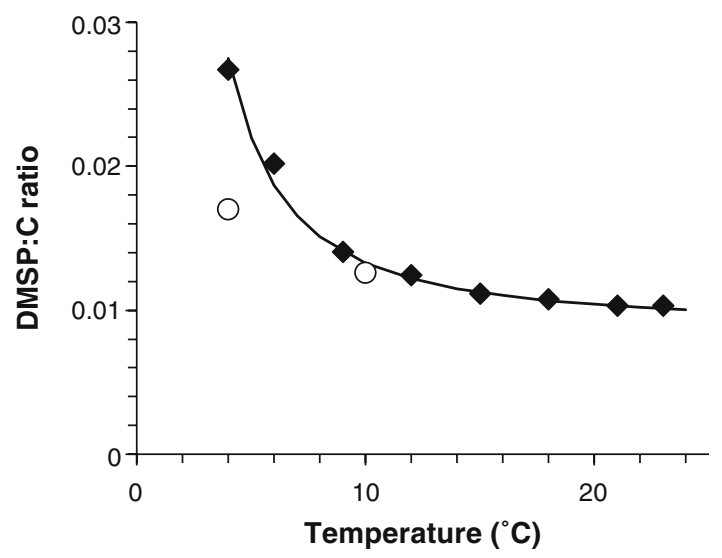

Fig. 4 Effect of temperature on the cellular DMSP:C-ratio (mol:mol) in Emiliania huxleyi (closed symbols; recalculated from van Rijssel and Gieskes (2002). For comparison, data from experiments with Phaeocystis antarctica $\left(4^{\circ} \mathrm{C}\right.$; Stefels and van Leeuwe 1998) and P. globosa $\left(10^{\circ} \mathrm{C}\right.$; Stefels and van Boekel 1993) are included. Except for P. antarctica, carbon data are calculated from cell volume data (see Table 1). Equation of the power fit to the E. huxleyi data is: DMSP:C $=0.009+0.17 T^{-1.6}$

\section{Temperature}

DMSP has been found to be a compatible solute for cell metabolism under cold conditions (Karsten et al. 1996; Nishiguchi and Somero 1992, reviewed in Stefels 2000). The observation that DMSP is present in many ice algae, including the diatoms, and in many pelagic algae from polar regions (Matrai and Vernet 1997) may be indicative of its functionality under cold conditions. Surprisingly, only two studies report on the acclimatisation of the intracellular DMSP concentration at various temperatures (Sheets and Rhodes 1996; van Rijssel and Gieskes 2002). Converting the Van Rijssel and Gieskes (2002) data on Emiliania huxleyi to DMSP:C ratios gives a correlation with temperature as shown in Fig. 4. The added data points for Phaeocystis are for P. globosa at $10^{\circ} \mathrm{C}$ and for $P$. antarctica at $4^{\circ} \mathrm{C}$ (J. Stefels unpublished data) and fall close to the E. huxleyi relationship. However, further data are needed to establish whether the same relationship holds for DMSP-producing species that do not belong to the haptophytes.

\section{Nutrients}

After Challenger (1951) had noticed the structural analogy between DMSP and glycine betaine (GBT), many have suggested that DMSP could replace GBT as an osmoregulator under nitrogen-limited conditions. Indeed, there are several reports of increased cellular DMSP content under N-limited growth, but there are also reports of the contrary (Stefels 2000 and refs. therein). As a whole, the effects of nutrient limitations on DMSP production are still enigmatic.

From a physiological point of view, the intracellular concentrations of organic solutes are most relevant, as it is this concentration that affects enzymatic processes. Shifting from unlimited towards limited growth in a batch culture, cell volume often reduces under nitrogen and iron limitation and stays constant under phosphate limitation. Therefore, an increased intracellular DMSP concentration under $\mathrm{N}$ or Fe limitation is at least partly due to a reduction in cell volume (Bucciarelli and Sunda 2003; Keller et al. 1999a; Stefels and van Leeuwe 1998).

From a modeller's point of view, it is more relevant whether or not the DMSP production can be related to primary production. A complicating factor is that under nutrient-limited conditions the concen- 


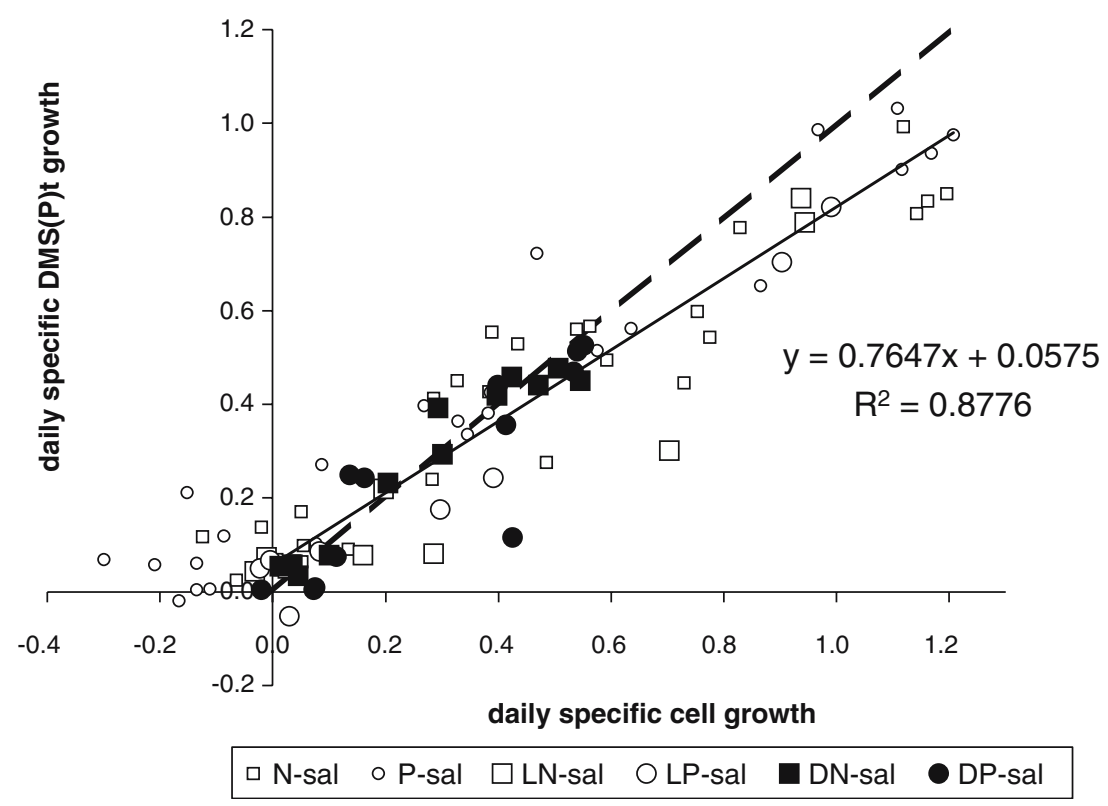

Fig. 5 Daily specific growth rates of total DMS + DMSP $_{d}+$ DMSP $_{p}$ versus specific cell growth in a variety of axenic Phaeocystis globosa batch cultures under different conditions. Cultures were grown at the same temperature $\left(11^{\circ} \mathrm{C}\right)$, but with different salinities, nutrient ratios and/or light conditions. Specific growth rates were calculated per day. Culture growth details are as follows: $\mathrm{N}$-sal: salinity range from 25 to 50 PSU, nitrogen limited; P-sal: salinity range from

trations of DMS and dissolved DMSP often increase, either due to cell lysis or to active exudation (Laroche et al. 1999). The question is how the total production of DMS and DMSP is related to algal growth. Unfortunately, total pools of $\mathrm{DMS}(\mathrm{P})$ are rarely presented in the literature. In Fig. 5, a compilation of experiments with Phaeocystis globosa is presented (unpublished data, J. Stefels), in which it is clearly shown that the specific DMS + DMSP production is coupled to cell growth and compares well under a variety of conditions: a range of salinities, low or high light conditions and either nitrogen or phosphorus limitation. The fact that the regression coefficient deviates from 1 reflects the observation that under unlimited (high) growth rates, cells tend to divide faster than they grow in terms of carbon, which results in a cell-size reduction during exponential growth. The positive $Y$-intercept indicates that at limited (low) cell growth, DMSP production continues under all conditions, even when cell numbers decline (negative growth). Whether this production is due to a few healthy cells that are still growing amidst
25 to 50 PSU, phosphate limited; LN-sal: high irradiance (120 $\mu \mathrm{mol}$ PFD), 30 and 40 PSU, nitrogen limited; LP-sal: high irradiance (120 $\mu \mathrm{mol}$ PFD), 30 and 40 PSU, phosphate limited; DN-sal: low irradiance (10 $\mu \mathrm{mol}$ PFD), 30 and 40 PSU, nitrogen limited; DP-sal: low irradiance (10 $\mu \mathrm{mol}$ PFD), 30 and 40 PSU, phosphate limited. Regression line is computed from data with positive specific cell growth only. Dashed line indicates a 1:1 relationship

a majority of inactive or dead cells, or because of a reaction to stress is unknown. This compilation shows that there is no increased production under stress conditions as suggested in the anti-oxidant hypothesis and that a modeller's practice of coupling DMSP production to cell growth is an appropriate approach.

A potential pitfall in carbon-based models is, however, the decoupling between cell growth and carbon growth, which would result in shifts of the DMSP:C ratios. Direct evidence for such a decoupling between the carbon and sulphur cycles is still lacking, but indirect evidence can be sought in calculated DMSP:C ratios relative to growth rates. In Fig. 6, a compilation of available data is given. In those cases where only cell volume data were available, cell carbon is calculated according to Menden-Deuer and Lessard (2000). This may result in an underestimation of cell carbon under $\mathrm{N}$ or $\mathrm{Fe}$ limitation (and thus an overestimation of the DMSP:C ratio), since, under those conditions, cells often become carbon denser, i.e., an increase in cell carbon per cell volume (Stefels and van Leeuwe 
1998). In the low-DMSP producing diatom Thalassiosira pseudonana a clear effect of nutrient limitation on DMSP:C ratios could be found, with highest ratios under $\mathrm{N}$ limitation and all other conditions comparable. However, in all other high-DMSP-producing species, changes of the ratio are negligible (see figure legend for description and references). This suggests that cells with a high DMSP content do not respond to nutrient limitation-or at least that a response in the DMSP production is too low to affect the DMSP:C ratio-whereas cells with low DMSP content do react. Modellers may implement this by assigning different behaviour towards nutrient limitation to different plankton groups in their model.

\section{Maintenance of intracellular DMSP}

concentration: algal DMSP-lyase activity

Algae can adjust the intracellular concentration of DMSP through the biosynthetic (anabolic) or the degradation (catabolic) pathways. DMSP-lyase enzymes facilitate the degradation pathway, in which DMSP is cleaved to DMS, acrylate and a proton. What controls the activity of DMSP-lyases in phytoplankton is still unknown. Stefels (2000) suggested

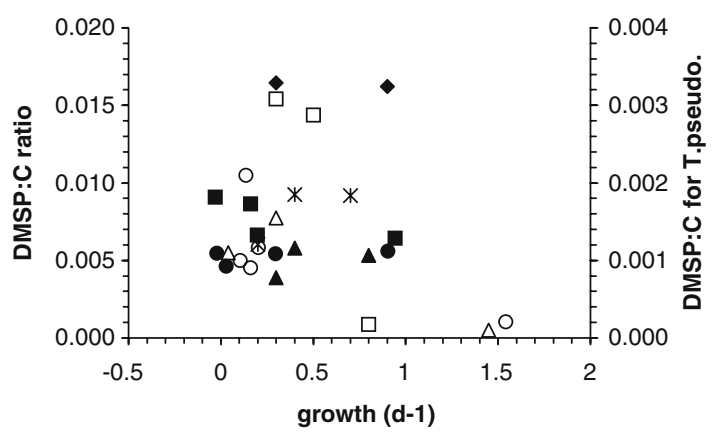

$\bullet P$. ant. Fe $\lim \bullet$ P. glob. $P \lim \square$ P. glob. $N \lim \Delta$ E. hux. $N \lim$ * Amph. $\mathrm{N} \lim \square \mathrm{T}$. pseudo $1 \quad \Delta \mathrm{T}$. pseudo $2 \quad$ OT.pseudo 3

Fig. 6 Cellular DMSP-to-carbon ratios (mol:mol) versus specific growth rates under various nutrient limited conditions. Phaeocystis antarctica: Fe limited (Stefels and van Leeuwe 1998); P. globosa: P and N limited (Stefels unpublished; carbon is calculated from cell volume; see Table 1); Emiliania huxleyi, Amphidinium carterae and Thalassiosira pseudonana 1: N-limited chemostats (Keller et al. 1999b); T. pseudonana 2: $\mathrm{Fe}$ and $\mathrm{CO}_{2}$ limited (Sunda et al. 2002; carbon is calculated from cell volume; see Table 1); T. pseudonana 3: N, P, Si and $\mathrm{CO}_{2}$ limited (data are taken from the exponential and early stationary phase of growth, Figs. 2-7 in Bucciarelli and Sunda 2003; carbon is calculated from cell volumes, see Table 1) that in the case of the production of DMSP as an overflow mechanism, the intracellular equilibrium concentration has to be regulated by its degradation rather than by its production. Since DMSP is a zwitter ion, this could be achieved by actively transporting DMSP out of the cell. Subsequent removal of DMSP from the transporter site by extracellular cleavage would facilitate the release, since concentration gradients are kept maximal. Such a mechanism would necessitate a membrane-bound extracellularly located DMSP-lyase. This is particularly relevant for organisms with a thick boundary layer such as Phaeocystis colonies. The idea of such a role for DMSP-lyase was instigated by the observations that Phaeocystis exhibits high in vivo lyase activities when dissolved DMSP is added to the culture medium and that extracellular inhibitors can repress this activity (Stefels and Dijkhuizen 1996). In addition, it has been observed that acrylate, one of the products of DMSP degradation, accumulates in the mucus layer of Phaeocystis colonies (Noordkamp et al. 2000), which is in agreement with an extracellular location of the enzyme. Sunda et al. (2002) suggested that DMSP-lyase is involved in the scavenging cascade that detoxifies cells of harmful oxygen radicals, as it facilitates the production of DMS and acrylate, two products that are highly efficient ROS scavengers. This hypothesis would favour an intracellular and possibly chloroplastic location of the lyase.

Despite being so central for the release of DMS, relatively little is known about DMSP-lyase and its physiological regulation. Molecular information on the genetic sequences of DMSP-lyases is lacking and it still is possible that nonspecific house-keeping enzymes that accept a wide range of substrates perform this reaction. In the studies done so far, both intra- and extracellular isozymes of DMSP-lyase have been found in several Emiliania huxleyi and Phaeocystis strains, apparently with different kinetic characteristics (Steinke et al. 1998; Stefels et al. in prep). Both studies conclude that DMSP-lyases are constitutively present and there is as yet no indication of up- or down-regulation by abiotic factors, although only few dedicated experiments have been carried out to date. Shifts in enzyme affinity during growth have been observed in batch cultures, but are as yet unexplained (Table 3; Stefels and van Boekel 1993; Steinke et al. unpublished data). In addition, several 


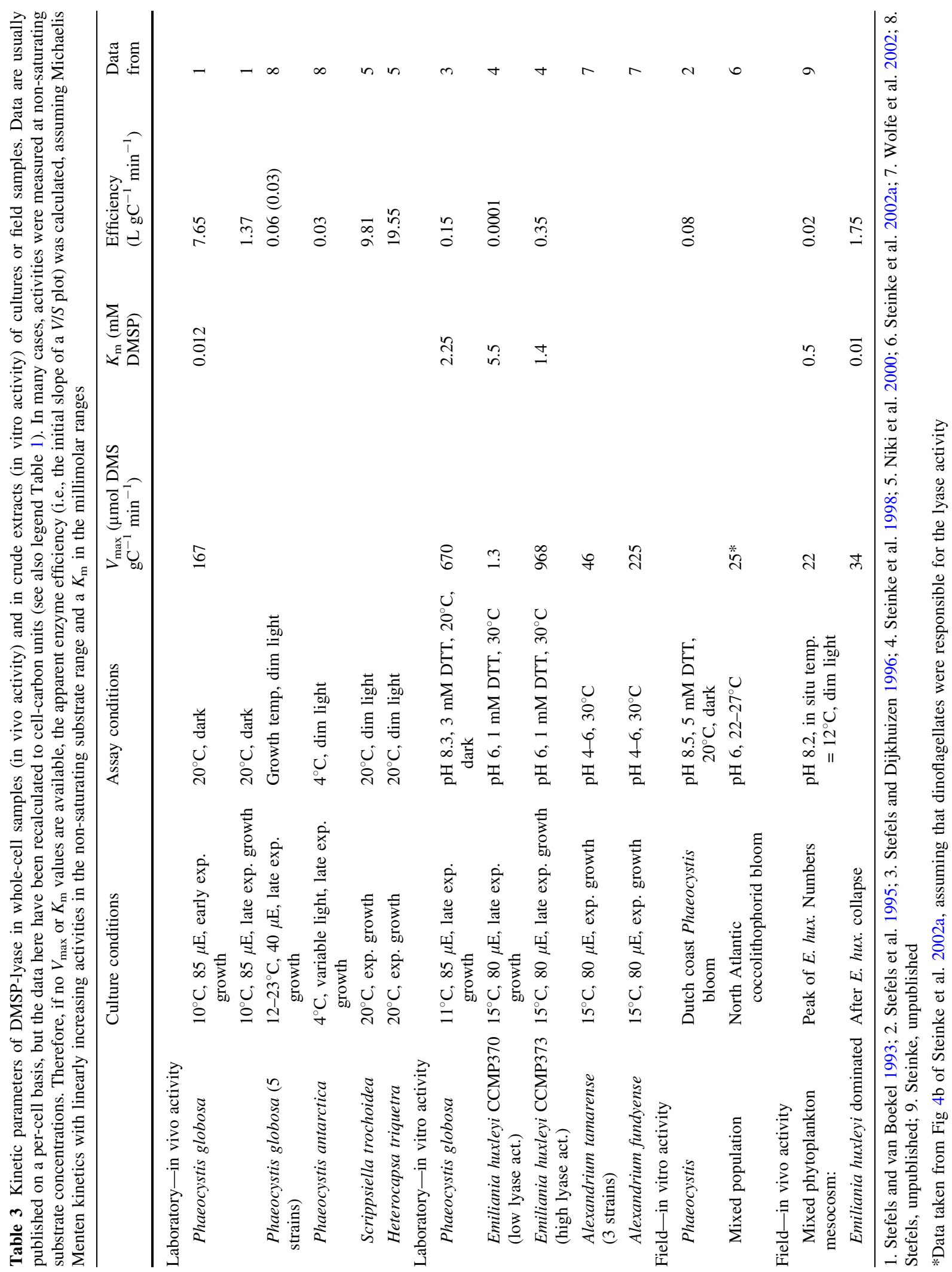


studies suggest that not all DMSP-producing algae have DMSP-lyase activity. Niki et al. (2000) tested five species of phytoplankton for their in vivo lyase activity, three of which did not show any activity. These were a non-DMSP-producing raphidophyte and two DMSP-producing haptophytes. A lack of DMSP-lyase activity was also found in a suite of DMSP-producing coccolithophorid species (Franklin et al. unpublished data). Steinke et al. (1996) did not find any in vitro lyase activity in the DMSPproducing prasinophyte Tetraselmis subcordiformis. Non-optimised assay conditions may contribute to these findings but this could also indicate that the ability to synthesise DMSP is not necessarily related to the presence of a DMSP-lyase, which makes the role of the enzyme all the more puzzling.

For modelling purposes two aspects of algal DMSP-lyases are relevant. Firstly, the activity of an extracellularly located enzyme may contribute to the conversion of the (ambient) dissolved DMSP pool. In this case, the apparent enzyme efficiency ( $\alpha$; i.e., the initial slope of a $V / S$ plot showing DMSP-lyase activity versus DMSP concentration) at ambient conditions obtained during in vivo assays is relevant. Secondly, the activity of intra- or extracellular enzymes may be crucial for the direct conversion of intracellular DMSP, after cells break up due to autolysis, viral attack or grazing (see below for a description of these processes). In these cases, one can envisage that the lyase, formerly separated from its substrate, is exposed to elevated DMSP concentrations, resulting in high production rates of DMS. The conversion rate of this DMSP might then be related to the $V_{\max }$ of the enzyme. In Table 3, we tried to make the available published data comparable by recalculating them on a cell-carbon basis.

Another important question is how algal lyase activity compares to bacterial activity. Although the latter will be discussed in the section 'Microbial consumption of DMSP', several studies on field samples indicate that algal lyase activity can be as important, if not more, as bacterial lyase activity. Stefels et al. (1995) found a strong correlation between Phaeocystis abundance and in vitro lyase activity in Dutch coastal waters. No lyase activity was found in size fractions $<10 \mu \mathrm{m}$. During sampling of a bloom of E. huxleyi in the North Atlantic, Steinke et al. (2002a) found $>74 \%$ of the in vitro lyase activity associated with particles $>10 \mu \mathrm{m}$ and suggested that dinoflagel- lates were responsible for this activity. Niki et al. (2000) calculated that the algal lyase pathway is as important as the bacterial lyase pathway, in samples from Tokyo Bay. Also other size fractionation experiments have shown that lyase activity is often associated with the large size fractions (Cantin et al. 1999; Scarratt et al. 2000), although it cannot be excluded that attached bacteria are partly responsible for this activity. In a modelling study of the seasonal evolution of DMS in the Southern Bight of the North Sea, van den Berg et al. (1996) showed that the presence of an algal DMSP-lyase associated with the occurrence of Phaeocystis was essential to properly describe the DMS spring peak.

These results suggest that for modelling purposes it might be beneficial to distinguish between phytoplankton groups with and without DMSP-lyase. The limited data we have so far suggest that the dinoflagellates and part of the haptophytes have DMSPlyase. This has been incorporated in our recommendation on plankton groups and their characteristics (section 'Conclusions'; Table 6).

\section{Fate of DMSP-sulphur}

Table 1 shows that the proportion of DMSP-carbon to the total cell-carbon in the different phytoplankton groups varies between $0 \%$ and $11 \%$. This suggests that this single component can be an important fraction of the labile dissolved organic carbon pool and therefore highly relevant as a carbon source for bacteria. It also indicates that the coupling of the fate of dissolved DMSP and that of DOC (Archer et al. 2004) might be promising in advancing future models. There is considerable evidence that in many marine areas the DMS that ultimately reaches the atmosphere accounts for only a small percentage of the DMSP-sulphur originally produced by the algae (e.g., Bates et al. 1994; Kiene and Bates 1990; Kiene and Service 1991). More recently, it was shown that this percentage yield can vary considerably (between $1 \%$ and $40 \%$ ) and can be correlated to the mixed layer depth (Simo and Pedros-Alio 1999a). Both biotic and abiotic processes will affect the yield of DMS from DMSP. We will first focus on those factors involved in the release and conversion of DMSP and then discuss processes affecting the consumption of DMS. 
Mechanisms of release to the dissolved fraction

Pathways through which particulate DMSP is released into the dissolved phase are active exudation, cell lysis due to senescence or to viral attack and grazing by zooplankton. In the many publications that describe these processes, this release is presented either in the form of dissolved DMSP $\left(\mathrm{DMSP}_{\mathrm{d}}\right)$ or in one of its degradation products. For models, however, an important question is whether this release goes through the dissolved DMSP pool, with subsequent conversion by bacterial and algal enzymes, or that release and conversion of the particulate DMSP pool is intrinsic to the release process. In the vicinity of or within a bursting cell, high-affinity enzyme systems will result in the rapid conversion of DMSP to DMS, whereas in the case of no or only low-affinity enzyme systems the same process may result in dissolved DMSP alone. The subsequent fate of $\mathrm{DMSP}_{\mathrm{d}}$ will then be consumption by bacteria with a DMS yield depending on the development of the bacterial community. The same release process may thus result in completely different DMS yields and therefore needs to be modelled differently for the different plankton groups.

A complicating factor in the evaluation of published data on the fractionation between dissolved and particulate DMSP is the potential for overestimations of $\mathrm{DMSP}_{\mathrm{d}}$, due to release from the cells during filtration (Kiene and Slezak 2006). $\mathrm{DMSP}_{\mathrm{d}}$ is taken to be the filter fraction of the less than $1 \mu \mathrm{m}$ fraction, but for fragile, DMSP-containing flagellates such as Phaeocystis, filtration can easily result in operational release of dissolved organic material from the cells. Any use of published data should, therefore, involve a thorough check of the analytical methods used for the quantification of $\mathrm{DMSP}_{\mathrm{d}}$. The following sections address the different mechanisms of release of DMSP-sulphur from algal cells.

\section{Exudation}

Information on active exudation of DMSP is limited. Laroche et al. (1999), using a modelling study, indicated that DMSP exudation in the dinoflagellate Prorocentrum minimum is independent of growth phase at the level of $1 \%$ of its DMSP quota per day. In contrast, they showed that Phaeocystis sp. exudation rates, measured as cumulative DMS concentration in the cultures, are highest at the end of logarithmic growth and account for $3-11 \%$ per day. DMSP in ice diatoms can be an important source of $\mathrm{DMSP}_{\mathrm{d}}$ and DMS, following ice break-up in polar waters when interstitial plankton communities are released from hypersaline porewaters into seawater of much lower salinity (Levasseur et al. 1994). The ability to remove and rapidly cleave DMSP to DMS may be advantageous under such circumstances but as yet ice algae have not been tested for the presence of DMSP lyases. Hence, the exudation of DMSP is species-specific and can be affected by abiotic parameters such as salinity and temperature shifts and nutrient limitation. It thus can be a significant source of $\mathrm{DMSP}_{\mathrm{d}}$ and, where active DMSP-lyase is present, DMS. Especially in stress situations, however, it will be difficult to distinguish active exudation as a physiological response from cell lysis.

\section{Autolysis}

Recent findings indicate a distinction between programmed cell death (PCD) or apoptosis-a form of autocatalytic cell suicide in which morphological and biochemical changes lead to cell dissolution-and necrosis, which is a passive form of cell death and leads to immediate cell rupture e.g., after injury (Bidle and Falkowski 2004). In multicellular organisms, PCD results in phagocytosis without releasing the cellular contents, whereas necrosis does result in release of cell content. Whether a comparable distinction can be made for phytoplankton cells is unknown. It has been suggested that in algae, initiation of PCD occurs under nutrient limited or otherwise stressful conditions and that PCD can be regarded as a refinement of the term autolysis (Bidle and Falkowski 2004). Autolysis has long been assigned as the prime pathway for release of particulate DMSP (Nguyen et al. 1988), since, at the end of a bloom, cells disintegrate and DMSP is released into the water. This process thus parallels possible active exudation by nutrient-limited cells that are alive.

\section{Viral lysis}

To date only a few studies have examined how viral infection and lysis of DMSP-containing cells affect the production of DMS. Malin et al. (1998) found that 
viral infection of a Phaeocystis pouchetii culture resulted in cell lysis and four fold increase of DMS after $20 \mathrm{~h}$. However, this strain was not axenic so it was not possible to ascertain whether the measured DMS derived directly from the algal cells or from bacterial conversion of DMSP to DMS. In contrast a parallel study on Micromonas pusilla showed DMSP release, but DMS production was only present in bacterised cultures (Hill et al. 1998). More recently Evans et al. (2007) have found that infected axenic cultures of Emiliania huxleyi do produce elevated levels of DMS (see Wilson et al. 2005 and references therein for more details of this virus/host system). Whether the quantity of DMS produced relates to the DMSP lyase activity of the host has yet to be proven. As far as we are aware there are no data concerning the activity of this enzyme in $M$. pusilla and viral pathogens of high-lyase E. huxleyi have only been isolated very recently (Matrai et al., pers. com.).

Whilst these culture studies suggest that viral lysis could be a significant DMS production pathway, quantification of the contribution of this process versus grazing or autolysis in natural plankton assemblages is challenging. Evans et al. (2003) used a modified dilution protocol on three successive days to estimate viral and grazing related mortality in a mesocosm population of Micromonas spp. They found turnover rates of $10 \%, 25 \%$ and $9 \%$ of the standing stock per day compared to a microzooplankton grazing turnover of $48 \%, 26 \%$ and $23 \%$ per day. This technique shows promise but has yet to be applied successfully in natural blooms of phytoplankton that contain high levels of DMSP, so at the present time we lack quantitative data for this process. Nevertheless, it is interesting to consider more qualitative data from field-based studies. Bratbak et al. (1995) conducted a mesocosm study where DMS and $\mathrm{DMSP}_{\mathrm{d}}$ levels did not respond to virusinduced termination of a bloom of E. huxleyi and reasoned that this was due to bacterial degradation which prevented the accumulation of these compounds. In a Lagrangian study of an E. huxleyi bloom in the Northern North Sea, Wilson et al. (2002) concluded that microzooplankton grazing out-competed viral infection. In contrast, in mesocosm studies in 2000 and 2003 (University of East Anglia group, unpublished data) we found substantial increase in DMS concentration concomitant with the virusinduced demise of E. huxleyi blooms. There is a clear need for reliable new tools that would allow for the quantification and differentiation of $\operatorname{DMS}(\mathrm{P})$ production by virus-induced mortality, mortality due to autolysis or grazing.

\section{Grazing by microzooplankton}

A first indication of an important role for the microbial foodweb in the conversion of DMSP to DMS was provided by size-fractionation experiments of field samples (Belviso et al. 1990; Christaki et al. 1996). A mechanistic explanation for the release of DMS during grazing was later provided by laboratory experiments. Wolfe and Steinke (1996) found that grazing by the herbivorous dinoflagellate Oxyrrhis marina, which engulf their prey by phagotrophy, could greatly increase the production of DMS and that the DMS yield of the ingested prey-DMSP was correlated to the in vitro lyase activity of the prey (Table 4). This led to the assumption that DMSP and DMSP-lyases are present in E. huxleyi but are segregated into different cell compartments and react with each other once they are mixed in the food vacuoles of microzooplankton after ingestion. Strom et al. (2003a) also found proportionality between DMS production and preyDMSP lyase activity in grazing experiments with $O$. marina and four E. huxleyi strains. The relationship between DMS yield and lyase activity of the prey, suggests that the predator merely accelerates the conversion of DMSP into DMS and does not affect the conversion pathways. Due to a lack of measurements, the fate of the unconverted prey DMSP in these experiments is unknown. In grazing experiments with another heterotrophic dinoflagellate, Gyrodinium dominans, Tang and Simo (2003) calculated that $32 \%$ and $44 \%$ of ingested prey DMSP was retained in the grazer, irrespective of the lyase activity of the prey (Table 4). This would roughly comply with a growth efficiency of 0.3 as has also been suggested by Archer et al. (2001b).

Since DMS production from DMSP results in equimolar concentrations of acrylate, a compound that has been attributed with antimicrobial properties (Sieburth 1960), grazing-induced DMSP cleavage could affect microbial grazers. Wolfe et al. (1997) tested the grazing behaviour of $O$. marina with lowand high-lyase E. huxleyi and mixed-prey experiments with the non-DMSP-producing chlorophyte Dunaliella tertiolecta. On the basis of the results, the authors suggested the existence of a grazing-activated 


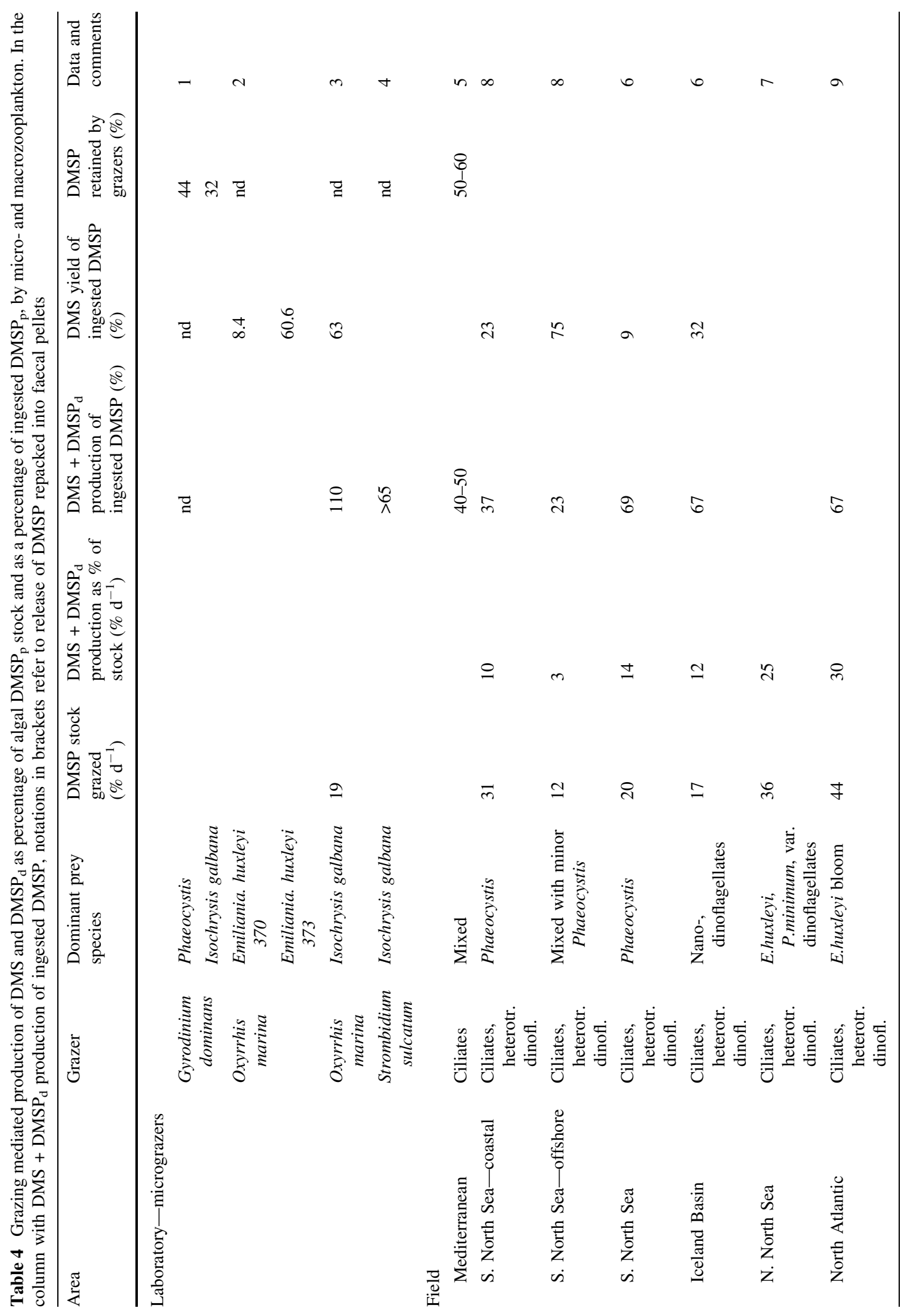




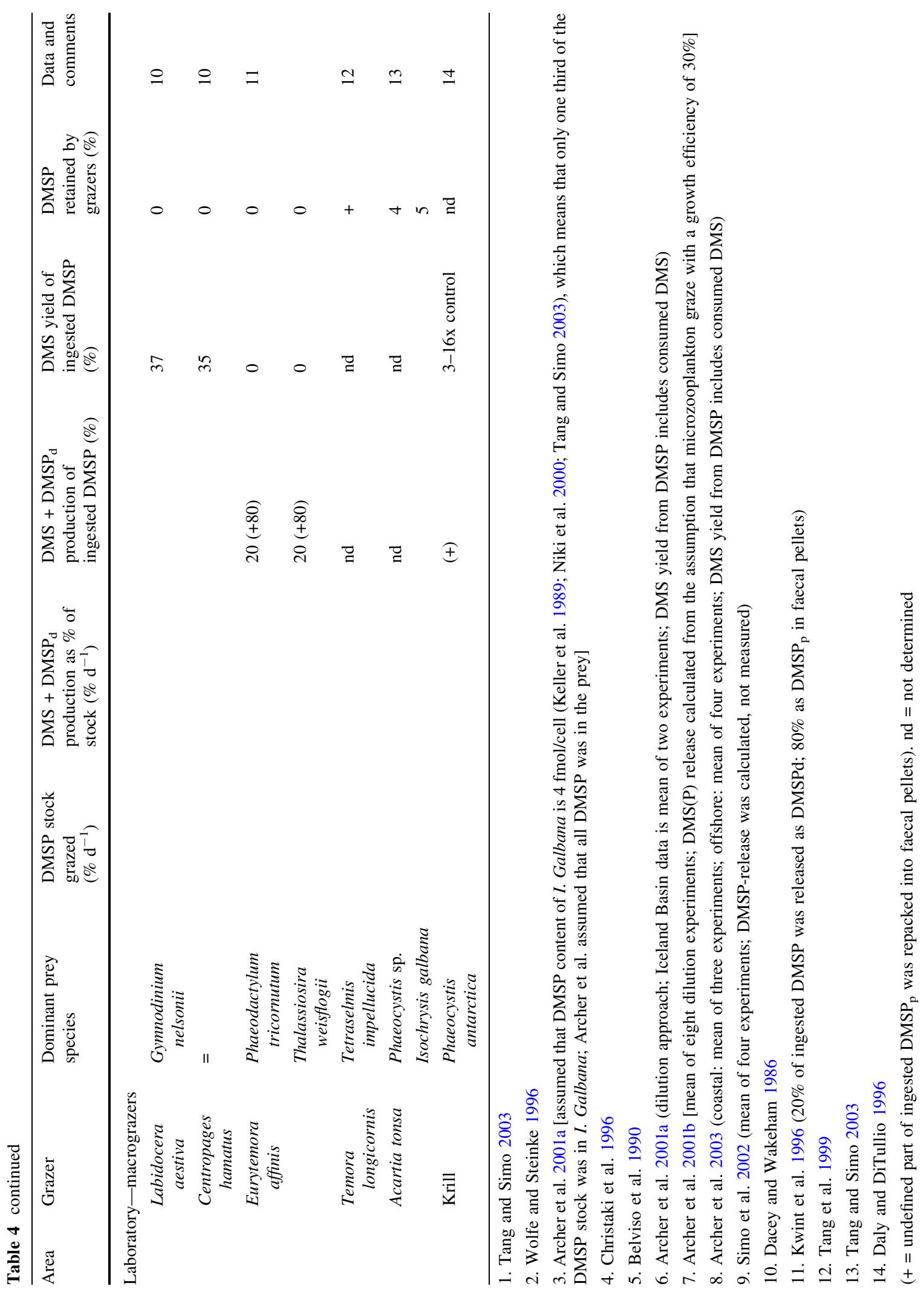


chemical defence mechanism based on acrylate. Such a mechanism could also be partly responsible for the significantly reduced feeding levels on high-lyase phytoplankton by other microzooplankton taxa (Strom et al. 2003a; Wolfe 2000). However, it was recently suggested that DMSP rather than acrylate is the active deterrent of microzooplankton grazing (Strom et al. 2003b) and readers are directed to the paper presented by Nejstgard et al. (this issue) for a discussion on this subject.

A few field experiments have combined the determination of microzooplankton grazing rates (the Landry-Hassett dilution technique) with DMS(P) analyses and have shown that DMSP-containing algal species may be proportionally less grazed than total algal biomass (Archer et al. 2001b; Olson and Strom 2002; Wolfe et al. 2000). However, several problems are associated with this technique and we refer to Archer et al. (2001b) for a discussion on the potential pitfalls. Nevertheless, the emerging picture is that generally $20 \%$ to $70 \%$ of the ingested DMSP $_{p}$ is released to the dissolved phase (Table 4). This is based on the assumption that no selective grazing takes place and all DMSP $_{p}$ is in algal cells. Since part of the $\mathrm{DMSP}_{\mathrm{p}}$ stock is in the micrograzers themselves, ingested DMSP $_{p}$ as calculated from grazing rates multiplied with the DMSP concentration may be an overestimation and hence the percentage converted to DMS and $\mathrm{DMSP}_{\mathrm{d}}$ an underestimation. In addition, possible selective grazing on none-DMSPcontaining algae and microbial consumption of DMS and $\mathrm{DMSP}_{\mathrm{d}}$ not resulting in DMS, will further increase the calculated percentage of ingested $\mathrm{DMSP}_{\mathrm{p}}$ being transferred to the dissolved pool. Archer et al. (2001b) therefore suggested that the transformation of algal DMSP through microzooplankton could simply be calculated from grazing rates by assuming a growth efficiency factor of 0.3 , which implies that $70 \%$ of the grazed DMSP is released to the dissolved pool or as faecal pellets. Tang and Simo (2003) showed that intracellular DMSP concentrations of a heterotrophic dinoflagellate vary passively with the DMSP content of the food source. If indeed microzooplankton do not regulate internal DMSP concentration for physiological purposes, the amount of DMSP retained by grazers and released to solution is a fixed percentage of DMSP consumption. The variation in DMS yield from exuded $\mathrm{DMSP}_{\mathrm{p}}$ is the result of a multitude of microbial processes, but seems to be at least partly related to the DMSP-lyase activity of the prey. Further refinement of methods is needed to fully understand the competing pathways.

\section{Grazing by meso- and macrozooplankton}

Grazing by larger zooplankton such as copepods and krill can increase the release of dissolved organic material by mechanical disruption of intact cells (sloppy feeding). This mechanism can result in the production of DMS (Dacey and Wakeham 1986; Daly and DiTullio 1996; Kasamatsu et al. 2004; Malin et al. 1994). In those cases, the release of $\mathrm{DMSP}_{d}$ during sloppy feeding may stimulate the conversion by algal or bacterial lyase enzymes, but microbial activity in the intestinal tract of the zooplankton and in faecal pellets may also be responsible for the high DMS production observed. Unfortunately, remarkably few dedicated grazing studies have published DMS and DMSP in both the dissolved and particulate phase necessary to draw a complete budget of the effect of grazing. When data are available, comparing the amount of DMSP ingested with the amount of DMS produced shows that a considerable part is lost (Table 4). Possible explanations are demethylation by bacteria in- or outside the grazer, storage of DMSP in the body tissues of some grazers (Tang et al. 1999) or repackaging of prey DMSP into faecal pellets (Kwint et al. 1996). The latter will result in high concentrations of DMSP in suspended material that could rapidly sink out of the euphotic zone and result in export of DMSP into deeper waters. The DMSP in this material appears to be readily available for biological degradation (see also 'Significance of vertical flux as a sink for particulate DMSP'), which does not necessarily result in the production of DMS (Kwint et al. 1996).

Phaeocystis colonies are considered to be less palatable to copepods than diatoms. This has mainly been attributed to the large size of these colonies. In addition it has been suggested that acrylate may accumulate to high concentrations in the mucus surrounding Phaeocystis colonies (Davidson and Marchant 1987; Guillard and Hellebust 1971). Since acrylate may have antimicrobial properties at elevated concentrations (Sieburth 1960; Slezak et al. 1994), DMSP-lyase could be involved in the accumulation of this compound to prevent microbial attack and grazing. In intact and growing Phaeocystis 
colonies, acrylate indeed appears to accumulate in the mucus to concentrations between $1 \mathrm{mM}$ and $7 \mathrm{mM}$ (Noordkamp et al. 1998 ,2000), but a direct impact on bacterial and grazing activities has not been established yet. Moreover, Phaeocystis can be readily grazed by krill, which results in elevated production of DMS (Daly and DiTullio 1996).

Evidently, the effect of macro-grazers on the sulphur budget depends on both the grazer and on the algae that are grazed. It appears that the most important role for copepods and krill is merely to be mediators in the release of DMSP through sloppy feeding or through repackaging into faecal pellets. Although there is limited evidence, we speculate that the amount of DMS produced from ingested DMSP is related to the DMSP-lyase activity of the prey, since DMS production was only observed in grazing experiments with Phaeocystis and a dinoflagellate, but not with diatoms (Table 4).

\section{Microbial consumption of DMSP}

The chemical half-life of DMSP in seawater is $>8$ years (Dacey and Blough 1987), which results in high abiotic stability under natural conditions (moderate temperatures and $\mathrm{pH}$ ). Therefore, most of the DMSP removal is through enzymatic processes. In the microbial food web, dissolved DMSP has many fates and several recent reviews on the microbial pathways and involved mechanisms have been published (Bentley and Chasteen 2004; Kiene et al. 2000; Lomans et al. 2002; Yoch 2002). They all show that DMSP can be readily used in a complex network of enzymatic conversions. This versatility indicates that this single compound is of major importance for the nutrition of the bacterial community. Indeed, several studies have shown that DMSP alone can contribute 1 to $15 \%$ of the total bacterial carbon demand in surface waters. Moreover, DMSP assimilation can satisfy most, if not all the, sulphur demand of marine bacteria (Kiene and Linn 2000; Simo et al. 2002; Zubkov et al. 2001). Since the focal point of this section is the quantification of DMSP removal, only the overall effects of the main pathways originating from DMSP (Fig. 1) will be discussed here.

The two major pathways of bacterial DMSP degradation are cleavage to DMS and acrylate and demethylation/demethiolation, with or without prior uptake into the cells. Quantitatively, the most important degradation pathway of DMSP, is demethylation. This pathway does not yield DMS, but 3methiolpropionate (MMPA) and, after a second demethylation, 3-mercaptopropionate (MPA). MMPA can also yield methanethiol (MeSH) after a demethiolation reaction. Next to DMS, MeSH is another important volatile sulphur compound. It is metabolised rapidly and appears to be the major sulphur source for the production of sulphur-containing amino acids and proteins in bacterioplankton (Kiene et al. 1999). Members of the Roseobacter group, a ubiquitous group of marine bacteria, are well known MeSH producers (Zubkov et al. 2001) and in waters rich in these bacteria, consumption of DMSP via demethylation can be tenfold higher than DMS production (Kiene et al. 2000).

The cleavage of DMSP in aerobic DMS-producing bacteria is thought to be similar to the cleavage by algae and differentiating between the two in field samples is thus a challenge. As far as this has been investigated, it appears that acrylate is further used as a carbon source, leaving DMS untouched (Yoch 2002 and references therein). The current three conceptual models for the uptake and metabolism of DMSP (Yoch 2002) suggest considerable diversity of DMSP-lyases amongst the bacteria. The presence of DMSP and DMSP-cleaving enzymes is a prerequisite but cannot be used as proxies for DMS production. Measurements in the Northeast Atlantic Ocean showed maximum in vitro DMSP-lyase activity (which indicates the potential for DMS production from both bacterial and algal enzymes) on the order of 6-185 nM DMS h${ }^{-1}$ (Steinke et al. 2002b), whereas in vivo DMS production (from short-term $(8 \mathrm{~h})$ bottle incubations) resulted in only $1.2-$ 14.4 nM DMS h-1 (Simo and Pedros-Alio 1999b).

A more extensive screening of 15 Roseobacter strains showed that the cleavage pathway was present in all strains and that the demethylation pathway cooccurred within five of these strains (Gonzalez et al. 1999). In addition, several strains were able to degrade DMS and MeSH. This versatility of sulphur metabolism within a single genus of bacteria indicates that identification of the community structure alone is insufficient to determine the dominating degradation pathways. Furthermore, the fact that several isolates were also able to consume DMS means that the difference between DMSP loss and DMS production in natural waters not necessarily 
indicates a dominance of the demethylation pathway. While considering the total myriad of conversion pathways, Kiene et al. (2000) proposed a hypothetical model that helps us to understand the relative importance of these pathways. These authors suggested that bacterioplankton will prefer the demethylation/demethiolation over the lyase pathway at low $\mathrm{DMSP}_{\mathrm{d}}$ concentrations. This is because this pathway provides more energetic benefits and it is a relatively economic way to assimilate reduced sulphur. In fact, it was proposed that the total sulphur demand of bacteria can be derived in this way and as such, this pathway can be directly linked to bacterial production. At higher DMSP $_{d}$ concentrations, the DMSP that is not assimilated is then available to the cleavage pathway. In other words, the fraction that is converted to DMS depends on the biomass and growth of the bacterial community. Kiene et al. (2000) also stipulated that it is not necessary for the $\mathrm{DMSP}_{\mathrm{d}}$ concentration to be high, but that it is the bacterial sulphur demand relative to the $\mathrm{DMSP}_{\mathrm{d}}$ availability that is critical. For instance, if sulphur demand is low due to nutrient limitation or UV stress, the demethylation pathway is minor and DMS yield may increase. Such a DMSP-availability hypothesis is consistent with the shifts in the relative contribution of the demethylation- and cleavage pathway, as observed by Simo and Pedros-Alio (1999a), who found DMS yields from consumed DMSP ranging between $5 \%$ and $100 \%$. These shifts were correlated to the depth of the mixed water layer, with higher DMS yields in shallow mixed layers, and could be related to UV stress on the bacterial population. In addition to this bacteria-oriented hypothesis, it appears that at high DMSPd concentrations, either in blooms or in microenvironments around algal cells or aggregates, the algal cleavage pathway may overrule the bacterial cleavage. For instance, the peak of the DMS concentration in Phaeocystis blooms is often associated with the younger parts of the bloom and not with the senescent part (van Duyl et al. 1998). This may be related to the fact that the bacterial community of younger blooms is often still developing and therefore their sulphur demand low. A relatively large proportion of $\mathrm{DMSP}_{\mathrm{p}}$ may then be rapidly converted to DMS by algal DMSP-lyases. During the senescent stages of the bloom, the mature bacterial community may divert DMSP into the demethylation pathway and/or consume a large proportion of the DMS. In terms of enzyme kinetics, one can envision that a plankton bloom diverts from a low affinity but high capacity cleavage system to a high-affinity but low-capacity demethylation/demethiolation system (Kiene et al. 2000).

The particulate DMSO pathway

In comparison to DMS and DMSP, the nonvolatile dimethyl sulphoxide (DMSO) is a poorly understood component of the marine sulphur cycle. In addition to DMSO being ubiquitous in seawater in the dissolved (or filterable $\mathrm{DMSO}_{\mathrm{d}}$ ) phase, evidence is also gathering for the direct production of particulate DMSO $\left(\mathrm{GF} / \mathrm{F}\right.$ retained $\left.\mathrm{DMSO}_{\mathrm{p}}\right)$ by cultures and natural assemblages of marine microalgae. DMSO has been the subject of three reviews (Hatton et al. 2004; Lee and de Mora 1999a; Lee and de Mora 1999b) and whilst we aim not to be overly repetitive here, it is nonetheless important to underline some pertinent information regarding particulate DMSO. This compound is remarkable in its ability to permeate intact biological membranes and it is well known as an effective radical scavenger. Indeed, it is widely used medically to deliver drugs through the skin and as a cryoprotectant for the storage of cells at freezer temperatures. This ability to transfer across membranes and the DMSP antioxidant cascade hypothesis put forward by Sunda et al. (2002) could explain the marked increase in $\mathrm{DMSO}_{\mathrm{d}}$ seen in dinoflagellate cultures as they approach and enter stationary phase (Simo et al. 1998). DMSO p production has been noted for cultures of the dinoflagellate Amphidinium carterae and the coccolithophorids Pleurochrysis carterae and E. huxleyi (Simo et al. 1998), suggesting that a wide range of phytoplankton may produce $\mathrm{DMSO}_{\mathrm{p}}$. Exponential phase cultures of A. carterae and E. huxleyi gave mean $\mathrm{DMSP}_{\mathrm{p}}: \mathrm{DMSO}_{\mathrm{p}}$ molar ratios of 25 and 8 , respectively. In a study of the Peruvian upwelling system Riseman and DiTullio (2004) found a strong positive correlation though with ratios of 0.7 to 4.2 , and they noted that concentrations of both sulphur pools and the antioxidant $\beta$-carotene increased under low-iron conditions which might be consistent with the production of free radicals due to iron deficiency. These authors provide a table that includes $\mathrm{DMSP}_{\mathrm{p}}$ : $\mathrm{DMSO}_{\mathrm{p}}$ values from five other studies that span the range 0.02-100. More recently Simo and Vila-Costa (2006) discussed 
geographic and temporal patterns of $\mathrm{DMSO}_{\mathrm{p}}$ distribution using the largest data set for $\mathrm{DMSO}_{\mathrm{p}}$ and DMSP $_{p}$ compiled to date. They report that the ratio of $\mathrm{DMSP}_{\mathrm{p}}: \mathrm{DMSO}_{\mathrm{p}}$ varied from 1 to 13 with an average of 5.2, and noted a trend towards higher proportions of $\mathrm{DMSO}_{\mathrm{p}}$ in phytoplankton in warmer seas. Further research is needed to better evaluate whether these variable ratios result from differences in phytoplankton speciation, bloom stages or prevailing growth conditions.

Significance of vertical flux as a sink for particulate DMSP

The significance of vertical flux as a sink for particulate DMSP was recently reviewed and reassessed using new data gained in coastal waters of northern Europe (Belviso et al. 2006 and references therein). Special attention was paid to the many biases that can affect estimates of downward fluxes of DMSP (catchment efficiency of traps, releases of particulate material to the dissolved pool, etc). A method was also suggested to correct DMSP fluxes from biological losses during the sedimentation process. Indeed, the lability of DMSP during the sedimentation process has been shown to be comparable to that of chlorophyll- $a$ (Cailliau et al. 1999). The chlorophyll- $a$ degradation products resulting from grazing and senescence are, in order of least to most degraded: phaeophytin- $a$, phaeophorbide- $a$ and pyrophaeophorbide- $a$. These phaeopigments can all be detected by high-performance liquid chromatography (HPLC). Assuming that phaeopigments trace the degradation products of DMSP, the following equation can be used to restore DMSP fluxes and to revise the daily vertical loss rates for DMSP:

$$
\begin{aligned}
F_{\mathrm{DMSP}, \text { revised }}= & F_{\mathrm{DMSP}, \text { observed }} \\
& \times[(\text { Chl } a+\text { Phaeo } a) /(\operatorname{chl} a)]
\end{aligned}
$$

Since grazing also provides products, not detected by HPLC and fluorometry, and since some of the DMSP is also lost in the form of DMSO (Hatton $2002 b)$ the revised export rates may still be underestimated. Nevertheless, Table 5 shows an updated picture of fluxes and export rates of DMSP for a number of different sites in open-ocean and coastal waters. Export rates of DMSP range between $0.1 \%$ and $16.6 \% \mathrm{~d}^{-1}$ in coastal waters and between $0.03 \%$ and $0.74 \% \mathrm{~d}^{-1}$ in the open ocean.

\section{Factors controlling DMS removal}

Bacterial consumption

In incubation studies with water samples from the equatorial Pacific, Kiene and Bates (1990) demonstrated that bacterial degradation of DMS dominated over sea-to-air gas exchange. The major microbial degradation pathways of DMS are consumption via DMS monooxygenases and methyltransferases and oxidation via DMS dehydrogenase. DMS can be oxidised to DMSO by a variety of sulphur and ammonia oxidisers, methylotrophs and phototrophs, which suggests that this is a versatile worldwide process (reviewed by Bentley and Chasteen 2004). The reverse reaction-reduction of DMSO to DMS via DMSO reductases under aerobic and anaerobic conditions is well known from laboratory studies, but as far as we are aware, this pathway has not been documented for any natural assemblage. The enzyme responsible for the conversion of DMS to $\mathrm{MeSH}$ and formaldehyde has long been thought to be DMS monooxygenase. However, both the enzyme and the metabolic pathway are enigmatic (Bentley and Chasteen 2004). Detailed biochemical and molecular level studies are needed to improve understanding of these important microbial processes. DMS can also be assimilated as a sulphur source although Zubkov et al. (2002) found this to be a minor pathway in the northern North Sea. However, it is interesting to note that Fuse et al. (2000) isolated a $\gamma$-proteobacterium Marinobacterium sp. that assimilated DMS at wavelengths of $380-480 \mathrm{~nm}$ via the production of heat-stable photosensitisers. A light-requiring mechanism like this would not operate under the dark incubation conditions that are often used for incubation experiments.

It is clear that bacterial activity is an important factor in reducing the quantity of DMS that is emitted to the atmosphere. Simo (2004) compiled data from several studies in different marine areas, which illustrates the linear relationship between biological DMS consumption and DMS production, and sug- 
Table 5 Values for the calculated correction factor for potential losses based on the phaeopigment to chlorophyll- $a$ ratio, the corrected daily downward flux of DMSPt, the

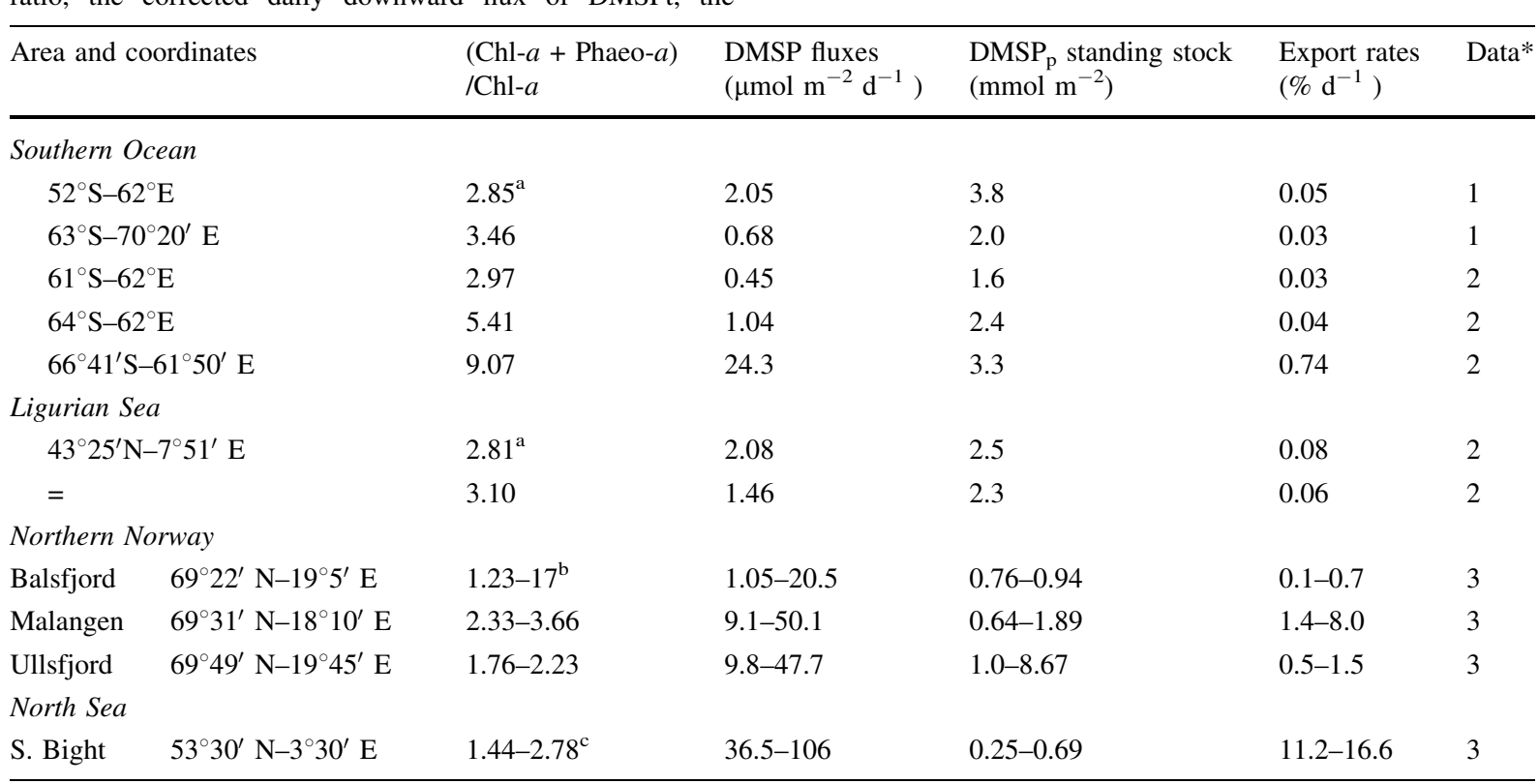

a Pigments measured by HPLC

b Pigments measured by fluorometry. Data digitised from Reigstad et al. (2000), Fig. 4

c Pigments measured by fluorometry

* Data are from: 1. Cailliau et al. 1999; 2. This study; 3. Belviso et al. 2006

gests that consumption accounts for between 50\% and $80 \%$ of the production. However, the significance of bacterial DMS consumption also alters depending on the strength of other, competing loss processes. Since all of these can alter rapidly according to meteorological forcing it is difficult to derive a range of widely applicable quantification terms. This is best illustrated by a study in the subpolar North Atlantic which showed that: (1) photochemical degradation dominated under clear skies and shallow mixing conditions, (2) bacterial consumption was most important when skies were cloudy and/or when the water column mixed to a greater depth and (3) loss of DMS due to sea-to-air transfer was roughly equivalent to bacterial consumption during a storm (Simo and Pedros-Alio 1999a).

\section{Photochemical oxidation of DMS}

Brimblecombe and Shooter (1986) established that photochemical oxidation is an important loss process for DMS, that the reaction rate varies with DMS seawater DMSP $\mathrm{p}_{\mathrm{p}}$ standing stocks and the revised daily vertical loss rates for DMSP at different sites 
$100 \mathrm{nM}$ tested), irradiance intensity and DOC concentration. However, we note that photolysis is most likely to be mediated by the portion of DOC that is known as coloured dissolved organic matter (CDOM). The apparent quantum yield for DMS also doubles with a temperature increase of $20^{\circ} \mathrm{C}$ (Toole et al. 2003). Interestingly nitrate concentrations are also relevant, in that Toole et al. (2004) found that in high-nitrate Antarctic waters $35 \%$ of the observed DMS photolysis was related to nitrate photochemistry and photolysis rates increased linearly with added nitrate. This nitrate dependence was also observed by Bouillon and Miller (2004). Moreover, Bouillon and Miller (2005) found that nitrate-induced photolysis of DMS was strongly enhanced by the presence of bromide ions and to a lesser extent by bicarbonate/ carbonate ions. Contrary to what was expected bicarbonate/carbonate-induced photolysis reduced with increasing $\mathrm{pH}$.

By pooling data from different oceanic regions, Hatton et al. (2004) found a highly significant correlation between DMS and DMSO in (near-)surface waters, with the DMSO concentration comparing to 1.5 times the DMS concentration. This clearly shows that photolysis is an important DMS loss process and that accurate photolysis parameterisations are needed to improve our understanding of DMS cycling and DMS models. Some of the studies mentioned above give DMS photolysis rates that are highly variable: $0.03-0.07 \mathrm{~h}^{-1}$ for the northern North Sea (Hatton 2002a), $0.12 \mathrm{~h}^{-1}$ for the coastal Adriatic (Brugger et al. 1998), $0.04 \mathrm{~h}^{-1}$ for the Pacific (Kieber et al. 1996), 0.026-0.086 $\mathrm{h}^{-1}$ for the western Atlantic (Toole et al. 2006) and $0.16-0.23 \mathrm{~h}^{-1}$ for the Antarctic (Toole et al. 2004). Given the previous discussion of CDOM, nitrate concentration, wavelength and temperature, all of which can vary with depth, we might conclude that an ideal parameterisation could be rather complex. For now modelling studies appear to use a variety of relatively simple approaches such that the DMS photolysis rate varies with depth and season (e.g., Archer et al. 2004; Lefevre et al. 2002).

Flux of DMS to the atmosphere

Until very recently there was no direct method for measuring the sea-air flux of DMS. Micrometeorological techniques are considered to be the best approach for determining fluxes (Businger and Delany 1990) but are a considerable technological challenge. Huebert et al. (2004) made the first measurements of DMS flux using the eddy correlation technique, on board ship. Their breakthrough was due to the development of the atmospheric pressure ionization mass spectrometer-isotopically labelled standard (APIMS-ILS) technique, which can measure DMS at high frequency. Another micrometeorological technique used recently for DMS is relaxed eddy accumulation (Zemmelink et al. 2004). Both methods require highly sophisticated equipment and specialist knowledge, so it is likely that the emission rates of DMS will continue to be determined by semi-empirical methods for some time to come.

The most widely used method for calculations of gas fluxes requires the concentration gradient between surface water and the atmosphere and a kinetic parameter known as the transfer or piston velocity (Liss and Slater 1974):

$F_{\mathrm{DMS}}=k_{(\mathrm{T})} \times \Delta C$

where $F_{\mathrm{DMS}}=$ net flux; $k_{(\mathrm{T})}=$ transfer velocity; $\Delta C=$ concentration gradient across the air-sea interface i.e., $C_{\mathrm{w}}-C_{\mathrm{a}} H^{-1}$, where $C_{\mathrm{w}}=$ concentration in water, $C_{\mathrm{a}}=$ concentration in air and $H=$ Henrys law constant. Since $C_{\mathrm{a}}$ is very low relative to $C_{\mathrm{w}}, C_{\mathrm{a}}$ is often taken to be zero, which generally may lead to an overestimation of about $6 \%$ or less which is not significant, relative to other uncertainties (Turner et al. 1996).

Over the last decade the results of oceanic multiple deliberate tracer experiments have refined existing estimates of $k$ (Nightingale et al. 2000) and, including the findings of the micrometeorological studies, there is still disagreement. Estimates vary by factors of about two and there is generally greater uncertainty for $k$ at higher wind speeds. What is agreed, however, is that wind speed alone is not adequate for the parameterization of $k$ and that other factors, such as surfactants and breaking wave bubble generation are important (e.g., Frew et al. 2004). Quantification of these parameters in the field is not straightforward and future measurement and modelling efforts are required before improvements in the quantification of $k$ can be achieved. 
The concentration term of the flux calculation also has major uncertainties, mainly associated with the spatial and temporal scales of measurements. These include bias towards Spring and Summer measurements with many areas of the world oceans still sparsely represented (Kettle et al. 1999). More important, in the context of ecosystem modelling and validation, is the uncertainty in measured DMS concentrations arising from the depth at which the samples are taken: operationally defined as surface water, but can be as deep as $11 \mathrm{~m}$. Vertical profiles of DMS concentration through the oceanic mixed layer are rarely homogenous and transient stratification (surface heating and freshwater input) can have marked affects (see Ward et al. 2004). At the smaller vertical scale of the sea-surface microlayer ( $\sim 60 \mu \mathrm{m}$ thickness) lies further uncertainty for the DMS concentration term. Study of the microlayer is technologically and logistically difficult and the few reports suggest a wide range of enrichments of DMS, relative to subsurface concentrations (e.g., 0.38-2.94, mean 1.1; Yang and Tsunogai 2005). It is not possible to assess the uncertainty of the DMS concentrations in the literature and further work is required to determine how important the depth of sampling is for a variety of biological and physical drivers and hence for the concentration term in the air-sea flux equation.

In summary, there is still a great deal of uncertainty in the calculation of sea-to-air fluxes and, for the time being, we recommend use of the transfer velocity parameterisation of Nightingale et al. (2000), which appears to be intermediate between all other estimations.

\section{Vertical and horizontal mixing of DMS}

Although oceanic mixing and stirring processes do not constitute loss of DMS per se, in dynamic oceanographic systems, dispersion and homogenisation can have significant control on the amount of DMS measured in the surface layer over timescales of hours and days. Vertical profiles of DMS in the mixed layer generally show some structure, often with a subsurface maximum. However, during highwind events increased mixing causes homogenisation of the upper water column and deepening of the mixed layer. Thus, in the course of a few hours the concentration of DMS at the surface can increase or decrease depending on the prior vertical profile structure and degree of enhanced turbulence. Post storms and during warm quiescent periods, when turbulence decreases, the mixed layer tends to shallow which causes DMS to be trapped below the new depth of the picnocline. This, in effect, reduces the size of the reservoir of DMS that is available for sea-to-air flux, inter alia.

Winds, currents and tides all contribute to horizontal mixing, which can also affect DMS concentrations. As an example, during a Lagrangian ironaddition experiment in the Southern Ocean a sulphurhexafluoride-labelled patch of water spread from about $70-1,000 \mathrm{~km}^{2}$ in 18 days which led to rapid dilution of the bloom with water containing low biomass and DMS (Turner et al., in prep). Vertical and horizontal mixing processes can thus be overruling loss processes after a local built-up of the DMS concentration, which warrants inclusion of these processes in models.

\section{Conclusions}

As we have shown in the previous sections, the transformation of DMSP to DMS and the accumulation of DMS in surface waters are intricately linked to food-web dynamics and physico-chemical processes, including photochemical degradation, vertical mixing, and sea to air flux. By recalculating and compiling current literature data we have provided an insight in the relative magnitude of different DMS-related processes. Hopefully, this will assist future modelling efforts to choose the most relevant processes and establish correct parameterisations. To our knowledge, Archer et al. (2004) has published the most complex ecosystem/DMS model to date, following on from the pioneering work done by Gabric et al. (1993). This model generates DMS(P) concentrations that are generally comparable with field data. It appears to be most sensitive to changes in DMSP as a proportion of total phytoplankton carbon and to the proportion of $\mathrm{DMSP}_{\mathrm{p}}$ that is transformed to $\mathrm{DMSP}_{\mathrm{d}}$ or DMS during excretion, lysis and grazing. The importance of correct intracellular DMSP quota was also shown by the model of Lefevre et al. (2002) for the subtropical North Atlantic, in which intracellular DMSP:N ratios varying with season and depth by a factor of five were needed to reproduce the field data. 
In the section 'Factors controlling DMSP production', we have given an update of the DMSP:C ratios in various phytoplankton groups and explained how abiotic factors can affect these ratios. Species composition has the largest impact on the DMSP:C ratio. Light and temperature appear to affect the DMSP:C ratio by a factor of 2-3 and nutrients may only have an effect on species with low levels of intracellular DMSP.

Another important feature recently recognised is the variation in DMS yield from consumed $\mathrm{DMSP}_{\mathrm{d}}$, ranging between $1 \%$ and $100 \%$. This appears not only to be related to the bacterial community structure and its productivity as presented in the DMSP-availability hypothesis of Kiene et al. (2000), but also to the ability of phytoplankton cells to cleave DMSP into DMS. There is ample evidence that within aggregates, during viral lysis, autolysis and grazing the DMS yield from released DMSP is related to the DMSP-lyase activity of the phytoplankton involved. This argues for the implementation of group-specific DMSP-lyase activity for algae in modelling studies. As a result, the DMS yield during grazing and lysis, but also the conversion of the dissolved DMSP pool will be affected by the dominant algal group. Van den Berg et al. (1996) already showed that this was vital to her model in order to reproduce the DMS peak during a Phaeocystis bloom. Nonetheless, groupspecific DMSP-lyase activity has not been implemented in recent models.

We recommend distinguishing six phytoplankton groups, based on their size, DMSP content, DMSPlyase activity and interactions with grazers (Table 6). The diatoms and dinoflagellates are taxonomically well defined and have for reasons of simplification been confined to the larger size class. The dinoflagellates are characterised by having DMSP-lyase. We propose that the diatoms are the only group in which nutrients have a distinct effect on the DMSP:C ratio. Although they have only low levels of DMSP, their global importance may make this nutrient dependency an important controlling factor. More dedicated experiments are needed to be able to quantify the effect of nutrient limitations on the DMSP content of other groups. The phytoflagellates are a highly diverse group that contains the haptophytes, including Phaeocystis and coccolithophorids, several larger prasinophytes, such as Tetraselmis, but possibly also the smaller dinoflagellates. Although this group also

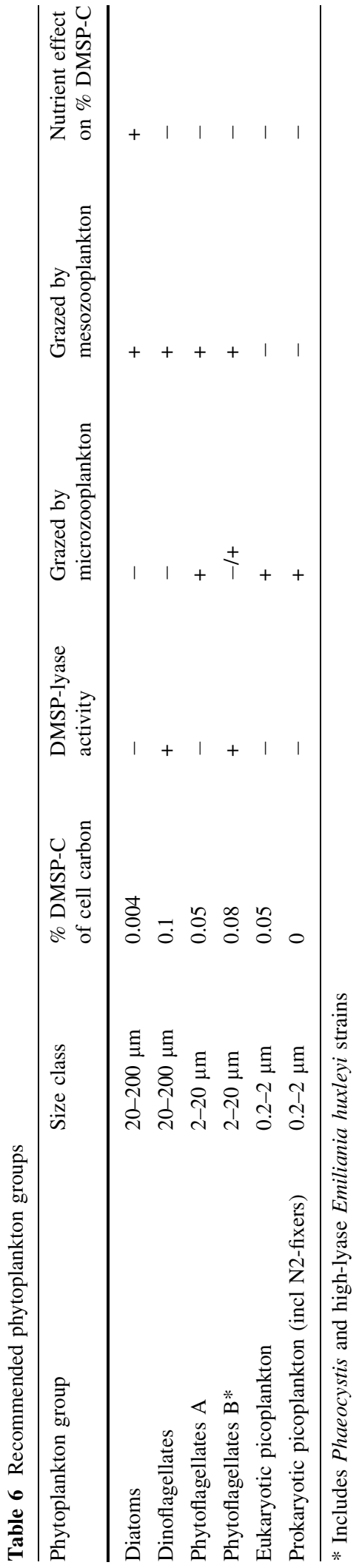


holds non-DMSP-containing algae, it seems justifiable from Table 1 to assign this group as DMSP producers. Given the importance of algal DMSPlyase activity, we propose the division of this group into two subgroups, based on this property: The phytoflagellates B contain DMSP-lyase and are represented by species such as Phaeocystis and E. huxleyi and possibly small dinoflagellates. They are potentially less grazed by microzooplankton than the phytoflagellates A, due to their DMSP-lyase activity. The picoplankton is a very heterogeneous group that is difficult to identify and describe for modelling purposes, but nonetheless very important for biogeochemical fluxes in open ocean areas. In order to address the heterogeneous nature of this group, we recommend separation between eukaryotic picoplankton, which do contribute to $\mathrm{DMSP}_{\mathrm{p}}$ and prokaryotic picoplankton, with no intracellular $\operatorname{DMSP}_{\mathrm{p}}$.

With the current overview, we hope to have given better insight into the various pathways and constraints; to have provided the modelling community with the means to parameterise these pathways in order to improve their models and to have highlighted areas where knowledge is limited and requires future laboratory and field studies.

Acknowledgements This is a contribution to the European Union IRONAGES project funded under contract N8 ENV4CT97-0472 by the Key Action Global Change of the Environment and Sustainable Development Programme of the European Commission and to the Scientific Committee on Oceanic Research (SCOR) working group 120 'Marine Phytoplankton and Global Climate Regulation: The Phaeocystis spp. Cluster as a Model'. GM thanks the Natural Environmental Research Council of the United Kingdom (NERC) for the award of a NERC advanced research fellowship (NERC NE/B501039/1) and additional grants for research on DMS (NER/T/S/2000/00638, NER/O/S/2001/ 01244, NER/A/S/2002/00917). MS was supported by a postdoctoral fellowship from the UK Natural Environment Research Council (NER/I/S/2000/00897 and NE/B500282/1).

\section{References}

Anderson TR, Spall SA, Yool A, Cipollini P, Challenor PG, Fasham MJR (2001) Global fields of sea surface dimethylsulfide predicted from chlorophyll, nutrients and light. J Mar Syst 30:1-20

Andreae MO (1990) Ocean-atmosphere interactions in the global biogeochemical sulfur cycle. Mar Chem 30:1-29

Andreae MO, Crutzen PJ (1997) Atmospheric aerosols: biogeochemical sources and role in atmospheric chemistry. Science 276:1052-1058
Andreae MO, Jones CD, Cox PM (2005) Strong present-day aerosol cooling implies a hot future. Nature 435:11871190

Archer SD, Gilbert FJ, Allen JI, Blackford J, Nightingale PD (2004) Modelling of the seasonal patterns of dimethylsulphide production and fate during 1989 at a site in the North Sea. Can J Fish Aquat Sci 61:765-787

Archer SD, Smith GC, Nightingale PD, Widdicombe CE, Tarran GA, Rees AP, Burkill PH (2002) Dynamics of particulate dimethylsulphoniopropionate during a Lagrangian experiment in the northern North Sea. DeepSea Res Part II 49:2979-2999

Archer SD, Stelfox-Widdicombe CE, Burkill PH, Malin G (2001a) A dilution approach to quantify the production of dissolved dimethylsulphoniopropionate and dimethyl sulphide due to microzooplankton herbivory. Aquat Microb Ecol 23:131-145

Archer SD, Stelfox-Widdicombe CE, Malin G, Burkill PH (2003) Is dimethyl sulphide production related to microzooplankton herbivory in the southern North Sea? J Plankton Res 25:235-242

Archer SD, Widdicombe CE, Tarran GA, Rees AP, Burkill PH (2001b) Production and turnover of particulate dimethylsulphoniopropionate during a coccolithophore bloom in the northern North Sea. Aquat Microb Ecol 24:225241

Aumont O, Belviso S, Monfray P (2002) Dimethylsulfoniopropionate (DMSP) and dimethylsulfide (DMS) sea surface distributions simulated from a global threedimensional ocean carbon cycle model. J Geophys ResOceans 107:Article no. 3029

Barnard WR, Andreae MO, Iverson RL (1984) Dimethylsulfide and Phaeocystis poucheti in the southeastern Bering sea. Cont Shelf Res 3:103-113

Bates TS, Charlson RJ, Gammon RH (1987) Evidence for the climatic role of marine biogenic sulphur. Nature 329:319321

Bates TS, Kiene RP, Wolfe GV, Matrai PA, Chavez FP, Buck KR, Blomquist BW, Cuhel RL (1994) The cycling of sulfur in surface seawater of the Northeast Pacific. J Geophys Res-Oceans 99:7835-7843

Bates TS, Lamb BK, Guenther A, Dignon J, Stoiber RE (1992) Sulfur emissions to the atmosphere from natural sources. J Atmos Chem 14:315-337

Baumann MEM, Brandini FP, Staubes R (1994) The influence of light and temperature on carbon-specific DMS release by cultures of Phaeocystis antarctica and three antarctic diatoms. Mar Chem 45:129-136

Belviso S, Kim SK, Rassoulzadegan F, Krajka B, Nguyen BC, Mihalopoulos N, Buatmenard P (1990) Production of Dimethylsulfonium Propionate (DMSP) and Dimethylsulfide (DMS) by a Microbial Food Web. Limnol Oceanogr 35:1810-1821

Belviso S, Thouzeau G, Schmidt S, Reigstad M, Wassmann P, Arashkevich E, Stefels J (2006) Significance of vertical flux as a sink for surface water DMSP and as a source for the sediment surface in coastal zones of northern Europe. Estuar Coast Shelf Sci 68:473-488

Bentley R, Chasteen TG (2004) Environmental VOSCs-formation and degradation of dimethyl sulfide, methanethiol and related materials. Chemosphere 55:291-317 
Bidle KD, Falkowski PG (2004) Cell death in planktonic, photosynthetic microorganisms. Nat Rev Microbiol 2:643-655

Bopp L, Aumont O, Belviso S, Monfray P (2003) Potential impact of climate change on marine dimethyl sulfide emissions. Tellus B 55:11-22

Bopp L, Boucher O, Aumont O, Belviso S, Dufresne JL, Pham M, Monfray P (2004) Will marine dimethylsulfide emissions amplify or alleviate global warming? A model study. Can J Fish Aquat Sci 61:826-835

Bouillon RC, Miller WL (2004) Determination of apparent quantum yield spectra of DMS photo-degradation in an in situ iron-induced Northeast Pacific Ocean bloom. Geophys. Res. Lett. 31:Article no. L06310

Bouillon RC, Miller WL (2005) Photodegradation of dimethyl sulfide (DMS) in natural waters: Laboratory assessment of the nitrate-photolysis-induced DMS oxidation. Environ Sci Technol 39:9471-9477

Bratbak G, Levasseur M, Michaud S, Cantin G, Fernandez E, Heimdal BR, Heldal M (1995) Viral activity in relation to Emiliania huxleyi blooms: A mechanism of DMSP release? Mar Ecol Prog Ser 128:133-142

Brimblecombe P, Shooter D (1986) Photo-oxidation of dimethylsulfide in aqueous solution. Mar Chem 19:343-353

Brugger A, Slezak D, Obernosterer I, Herndl GJ (1998) Photolysis of dimethylsulfide in the northern Adriatic Sea: Dependence on substrate concentration, irradiance and DOC concentration. Mar Chem 59:321-331

Bucciarelli E, Sunda WG (2003) Influence of $\mathrm{CO}_{2}$, nitrate, phosphate, and silicate limitation on intracellular dimethylsulfoniopropionate in batch cultures of the coastal diatom Thalassiosira pseudonana. Limnol Oceanogr 48:2256-2265

Businger JA, Delany AC (1990) Chemical Sensor Resolution Required For Measuring Surface Fluxes By 3 Common Micrometeorological Techniques. J Atmos Chem 10:399410

Cailliau C, Belviso S, Goutx M, Bedo A, Park Y, Charriaud E (1999) Sedimentation pathways in the Indian sector of the Southern Ocean during a production regime dominated by regeneration. Mar Ecol Prog Ser 190:53-67

Cantin G, Levasseur M, Schultes S, Michaud S (1999) Dimethylsulfide (DMS) production by size-fractionated particles in the Labrador Sea. Aquat Microb Ecol 19:307-312

Challenger F (1951) Biological methylation. Adv Enzymol 12:429-491

Charlson RJ, Lovelock JE, Andreae MO, Warren SG (1987) Oceanic phytoplankton, atmospheric sulphur, cloud albedo and climate. Nature 326:655-661

Christaki U, Belviso S, Dolan JR, Corn M (1996) Assessment of the role of copepods and ciliates in the release to solution of particulate DMSP. Mar Ecol Prog Ser 141:119-127

Corn M, Belviso S, Partensky F, Simon N, Christaki U (1996) Origin and importance of picoplanktonic DMSP. In: Kiene RP, Visscher PT, Keller MD, Kirst GO (eds) Biological and environmental chemistry of DMSP and related sulfonium compounds. Plenum Press, New York, pp 191-201

Crocker KM, Ondrusek ME, Petty RL, Smith RC (1995) Dimethylsulfide, algal pigments and light in an Antarctic Phaeocystis sp. bloom. Marine Biol 124:335-340
Curran MAJ, Jones GB, Burton H (1998) Spatial distribution of dimethylsulfide and dimethylsulfoniopropionate in the Australasian sector of the Southern Ocean. J Geophys Res-Atmos 103:16677-16689

Dacey JWH, Blough N (1987) Hydroxide decomposition of dimethylsulfoniopropionate to form dimethylsulfide. Geophys Res Lett 14:1246-1249

Dacey JWH, Wakeham SG (1986) Oceanic dimethylsulfide: production during zooplankton grazing. Science 233:1314-1316

Daly KL, DiTullio GR (1996) Particulate dimethylsulfoniopropionate removal and dimethylsulfide production by zooplankton in the Southern Ocean. In: Kiene RP, Visscher PT, Keller MD, Kirst GO (eds) Biological and environmental chemistry of DMSP and related sulfonium compounds. Plenum Press, New York, pp 223-238

Davidson AT, Marchant HJ (1987) Binding of manganese by Antarctic Phaeocystis pouchetii and the role of bacteria in its release. Marine Biol 95:481-487

DiTullio GR, Smith WO (1995) Relationship Between Dimethylsulfide And Phytoplankton Pigment Concentrations In The Ross Sea, Antarctica. Deep-Sea Res Part I 42:873892

Evans C, Archer SD, Jacquet S, Wilson WH (2003) Direct estimates of the contribution of viral lysis and microzooplankton grazing to the decline of a Micromonas spp. population. Aquat Microb Ecol 30:207-219

Evans C, Kadner SV, Darroch LJ, Wilson WH, Liss PS, Malin G (2007) The relative significance of viral lysis and microzooplankton grazing as pathways of dimethylsulfoniopropionate (DMSP) cleavage: An Emiliania huxleyi culture study. Limnol Oceanogr (in press)

Frew NM, Bock EJ, Schimpf U, Hara T, Haussecker H, Edson JB, McGillis WR, Nelson RK, McKenna SP, Uz BM, Jahne B (2004) Air-sea gas transfer: Its dependence on wind stress, small-scale roughness, and surface films. J. Geophys. Res.-Oceans 109:Article no. C08S17

Fuse H, Takimura O, Murakami K, Yamaoka Y, Omori T (2000) Utilization of dimethyl sulfide as a sulfur source with the aid of light by Marinobacterium sp strain DMSS1. Appl Environ Microbiol 66:5527-5532

Gabric A, Murray N, Stone L, Kohl M (1993) Modeling the production of dimethylsulfide during a phytoplankton bloom. J Geophys Res-Oceans 98:22805-22816

Gabric AJ, Simo R, Cropp RA, Hirst AC, Dachs J (2004) Modeling estimates of the global emission of dimethylsulfide under enhanced greenhouse conditions. Global Biogeochem Cycles 18:Article no. GB2014

Gage DA, Rhodes D, Nolte KD, Hicks WA, Leustek T, Cooper AJL, Hanson AD (1997) A new route for synthesis of dimethylsulphoniopropionate in marine algae. Nature 387:891-894

Geider RJ (1987) Light and temperature-dependence of the carbon to chlorophyll- $a$ ratio in microalgae and Cyanobacteria-Implications for physiology and growth of phytoplankton. New Phytol 106:1-34

Gibson JAE, Garrick RC, Burton HR, McTaggart AR (1990) Dimethylsulfide and the alga Phaeocystis pouchetii in antarctic coastal waters. Mar Chem 104:339-346

Gondwe M, Krol M, Gieskes W, Klaassen W, de Baar H (2003) The contribution of ocean-leaving DMS to the 
global atmospheric burdens of DMS, MSA, SO2, and NSS SO4=. Global Biogeochem. Cycles 17:Article no. 1056

Gonzalez JM, Kiene RP, Moran MA (1999) Transformation of sulfur compounds by an abundant lineage of marine bacteria in the alpha-subclass of the class Proteobacteria. Appl Environ Microbiol 65:3810-3819

Guillard RRL, Hellebust JA (1971) Growth and the production of extracellular substances by two strains of Phaeocystis pouchetii. J Phycol 7:330-338

Hatton AD (2002a) Influence of photochemistry on the marine biogeochemical cycle of dimethylsulphide in the northern North Sea. Deep-Sea Res Part II 49:3039-3052

Hatton AD (2002b) DMSP removal and DMSO production in sedimenting particulate matter in the northern North Sea. Deep-Sea Res Part II 49:3053-3065

Hatton AD, Darroch L, Malin G (2004) The role of dimethylsulphoxide in the marine biogeochemical cycle of dimethylsulphide. Oceanogr Mar Biol Ann Rev 42:29-55

Hill RW, White BA, Cottrell MT, Dacey JWH (1998) Virusmediated total release of dimethylsulfoniopropionate from marine phytoplankton: a potential climate process. Aquat Microb Ecol 14:1-6

Holligan PM, Fernandez E, Aiken J, Balch WM, Boyd P, Burkill PH, Finch M, Groom SB, Malin G, Muller K, Purdie DA, Robinson C, Trees CC, Turner SM, Vanderwal P (1993) A Biogeochemical Study Of The Coccolithophore, Emiliania-Huxleyi, In The North-Atlantic. Global Biogeochem Cycles 7:879-900

Holligan PM, Turner SM, Liss PS (1987) Measurements of dimethyl sulphide in frontal regions. Cont Shelf Res 7:213-224

Huebert BJ, Blomquist BW, Hare JE, Fairall CW, Johnson JE, Bates TS (2004) Measurement of the sea-air DMS flux and transfer velocity using eddy correlation. Geophys Res Lett 31:Article no. L23113

Karsten U, Kück K, Vogt C, Kirst GO (1996) Dimethylsulfoniopropionate production in phototrophic organisms and its physiological function as a cryoprotectant. In: Kiene RP, Visscher PT, Keller MD, Kirst GO (eds) Biological and environmental chemistry of DMSP and related sulfonium compounds. Plenum Press, New York, pp 143153

Kasamatsu N, Kawaguchi S, Watanabe S, Odate T, Fukuchi M (2004) Possible impacts of zooplankton grazing on dimethylsulfide production in the Antarctic Ocean. Can J Fish Aquat Sci 61:736-743

Keller MD, Bellows WK, Guillard RRL (1989) Dimethyl sulfide production in marine phytoplankton. In: Saltzman ES, Cooper WJ (eds) Biogenic sulfur in the environment. American Chemical Society, Washington DC, pp 167182

Keller MD, Kiene RP, Matrai PA, Bellows WK (1999a) Production of glycine betaine and dimethylsulfoniopropionate in marine phytoplankton. I Batch cultures. Marine Biol 135:237-248

Keller MD, Kiene RP, Matrai PA, Bellows WK (1999b) Production of glycine betaine and dimethylsulfoniopropionate in marine phytoplankton. II. N-limited chemostat cultures. Marine Biol 135:249-257

Keller MD, Korjeff-Bellows W (1996) Physiological aspects of the production of dimethylsulfoniopropionate (DMSP) by marine phytoplankton. In: Kiene RP, Visscher PT, Keller MD, Kirst GO (eds) Biological and environmental chemistry of DMSP and related sulfonium compounds. Plenum Press, New York, pp 131-142

Kettle AJ, Andreae MO (2000) Flux of dimethylsulfide from the oceans: A comparison of updated data seas and flux models. J Geophys Res-Atmos 105:26793-26808

Kettle AJ, Andreae MO, Amouroux D, Andreae TW, Bates TS, Berresheim H, Bingemer H, Boniforti R, Curran MAJ, DiTullio GR, Helas G, Jones GB, Keller MD, Kiene RP, Leck C, Levasseur M, Malin G, Maspero M, Matrai P, McTaggart AR, Mihalopoulos N, Nguyen BC, Novo A, Putaud JP, Rapsomanikis S, Roberts G, Schebeske G, Sharma S, Simo R, Staubes R, Turner S, Uher G (1999) A global database of sea surface dimethylsulfide (DMS) measurements and a procedure to predict sea surface DMS as a function of latitude, longitude, and month. Global Biogeochem Cycles 13:399-444

Kieber DJ, Jiao JF, Kiene RP, Bates TS (1996) Impact of dimethylsulfide photochemistry on methyl sulfur cycling in the equatorial Pacific Ocean. J Geophys Res-Oceans 101:3715-3722

Kiene RP, Bates TS (1990) Biological removal of dimethyl sulfide from sea water. Nature 345:702-705

Kiene RP, Linn LJ (2000) Distribution and turnover of dissolved DMSP and its relationship with bacterial production and dimethylsulfide in the Gulf of Mexico. Limnol Oceanogr 45:849-861

Kiene RP, Linn LJ, Bruton JA (2000) New and important roles for DMSP in marine microbial communities. J Sea Res 43:209-224

Kiene RP, Linn LJ, Gonzalez J, Moran MA, Bruton JA (1999) Dimethylsulfoniopropionate and methanethiol are important precursors of methionine and protein-sulfur in marine bacterioplankton. Appl Environ Microbiol 65:4549-4558

Kiene RP, Service SK (1991) Decomposition of dissolved DMSP and DMS in estuarine waters-Dependence on temperature and substrate concentration. Mar Ecol Prog Ser 76:1-11

Kiene RP, Slezak D (2006) Low dissolved DMSP concentrations in seawater revealed by small volume gravity filtration and dialysis sampling. Limnol Oceanogr Methods 4:80-95

Kirst GO, Thiel C, Wolff H, Nothnagel J, Wanzek M, Ulmke R (1991) Dimethylsulfoniopropionate (DMSP) in ice-algae and its possible biological role. Mar Chem 35:381-388

Kwint RLJ, Irigoien X, Kramer KJM (1996) Copepods and DMSP. In: Kiene RP, Visscher PT, Keller MD, Kirst GO (eds) Biological and environmental chemistry of DMSP and related sulfonium compounds. Plenum Press, New York, pp 239-252

Kwint RLJ, Kramer KJM (1996) The annual cycle of the production and fate of DMS and DMSP in a marine coastal system. Mar Ecol Prog Ser 134:217-224

Laroche D, Vezina AF, Levasseur M, Gosselin M, Stefels J, Keller MD, Matrai PA, Kwint RLJ (1999) DMSP synthesis and exudation in phytoplankton: a modeling approach. Mar Ecol Prog Ser 180:37-49

Lee PA, de Mora SJ (1999a) A review of dimethylsulfoxide in aquatic environments. Atmosphere-Ocean 37:439-456 
Lee PA, de Mora SJ (1999b) Intracellular dimethylsulfoxide (DMSO) in unicellular marine algae: Speculations on its origin and possible biological, role. J Phycol 35:8-18

Lefevre M, Vezina A, Levasseur M, Dacey JWH (2002) A model of dimethylsulfide dynamics for the subtropical North Atlantic. Deep-Sea Res Part I 49:2221-2239

Levasseur M, Gosselin M, Michaud S (1994) A New Source of Dimethylsulfide (DMS) for the Arctic Atmosphere - Ice Diatoms. Marine Biol 121:381-387

Liss PS, Malin G, Turner SM, Holligan PM (1994) Dimethyl Sulfide And Phaeocystis - A Review. J Mar Syst 5:41-53

Liss PS, Slater PG (1974) Flux of gases across the air-sea interface. Nature 247:181-184

Lomans BP, van der Drift C, Pol A, Op den Camp HJM (2002) Microbial cycling of volatile organic sulfur compounds. Cell Mol Life Sci 59:575-588

Malin G, Kirst GO (1997) Algal production of dimethyl sulfide and its atmospheric role. J Phycol 33:889-896

Malin G, Liss PS, Turner SM (1994) Dimethyl sulfide: production and atmospheric consequences. In: Green JC, Leadbeater BSC (eds) The Haptophyte Algae. Clarendon Press, Oxford, pp 303-320

Malin G, Turner S, Liss P, Holligan P, Harbour D (1993) Dimethylsulfide and Dimethylsulphoniopropionate in the Northeast Atlantic During the Summer Coccolithophore Bloom. Deep-Sea Res Part I 40:1487-1508

Malin G, Wilson WH, Bratbak G, Liss PS, Mann NH (1998) Elevated production of dimethylsulfide resulting from viral infection of cultures of Phaeocystis pouchetii. Limnol Oceanogr 43:1389-1393

Matrai PA, Keller MD (1993) Dimethylsulfide In A LargeScale Coccolithophore Bloom In The Gulf Of Maine. Cont Shelf Res 13:831-843

Matrai PA, Vernet M (1997) Dynamics of the vernal bloom in the marginal ice zone of the Barents Sea: Dimethyl sulfide and dimethylsulfoniopropionate budgets. J Geophys ResOceans 102:22965-22979

Menden-Deuer S, Lessard EJ (2000) Carbon to volume relationships for dinoflagellates, diatoms, and other protist plankton. Limnol Oceanogr 45:569-579

Mitchell JFB, Johns TC, Gregory JM, Tett SFB (1995) Climate response to increasing levels of greenhouse gases and sulphate aerosols. Nature 376:501-504

Nguyen BC, Belviso S, Mihalopoulos N, Gostan J, Nival P (1988) Dimethyl Sulfide Production During Natural Phytoplanktonic Blooms. Mar Chem 24:133-141

Nightingale PD, Malin G, Law CS, Watson AJ, Liss PS, Liddicoat MI, Boutin J, Upstill-Goddard RC (2000) In situ evaluation of air-sea gas exchange parameterizations using novel conservative and volatile tracers. Global Biogeochem Cycles 14:373-387

Niki T, Kunugi M, Otsuki A (2000) DMSP-lyase activity in five marine phytoplankton species: its potential importance in DMS production. Marine Biol 136:759-764

Nishiguchi MK, Somero GN (1992) Temperature- and concentration-dependence of compatibility of the organic osmolyte $\quad$-dimethylsulfoniopropionate. Cryobiol 29:118-124

Nejstgaard JC, Tang KW, Steinke M, Dutz J, Koski M, Antajan E, Long JD (2007) Zooplankton grazing on Phaeocystis: a quantitative review and future challenges. Biogeochemistry doi:10.1007/s10533-007-9098-y

Noordkamp DJB, Gieskes WWC, Gottschal JC, Forney LJ, van Rijssel M (2000) Acrylate in Phaeocystis colonies does not affect the surrounding bacteria. J Sea Res 43:287-296

Noordkamp DJB, Schotten M, Gieskes WWC, Forney LJ, Gottschal JC, van Rijssel M (1998) High acrylate concentrations in the mucus of Phaeocystis globosa colonies. Aquat Microb Ecol 16:45-52

Olson MB, Strom SL (2002) Phytoplankton growth, microzooplankton herbivory and community structure in the southeast Bering Sea: insight into the formation and temporal persistence of an Emiliania huxleyi bloom. Deep-Sea Res Part II 49:5969-5990

Paasche E (2001) A review of the coccolithophorid Emiliania huxleyi (Prymnesiophyceae), with particular reference to growth, coccolith formation, and calcification-photosynthesis interactions. Phycologia 40:503-529

Reigstad M, Wassmann P, Ratkova T, Arashkevich E, Pasternak A, Oygarden S (2000) Comparison of the springtime vertical export of biogenic matter in three northern Norwegian fjords. Mar Ecol Prog Ser 201:73-89

Riseman SF, DiTullio GR (2004) Particulate dimethylsulfoniopropionate and dimethylsulfoxide in relation to iron availability and algal community structure in the Peru Upwelling System. Can J Fish Aquat Sci 61:721-735

Scarratt M, Cantin G, Levasseur M, Michaud S (2000) Particle size-fractionated kinetics of DMS production: where does DMSP cleavage occur at the microscale? J Sea Res 43:245-252

Sheets EB, Rhodes D (1996) Determination of DMSP and other onium compounds in Tetraselmis subcordiformis by plasma desorption mass spectrometry. In: Kiene RP, Visscher PT, Keller MD, Kirst GO (eds) Biological and environmental chemistry of DMSP and related sulfonium compounds. Plenum Press, New York, pp 55-63

Sieburth JM (1960) Acrylic acid, an "antibiotic" principle in Phaeocystis blooms in Antarctic waters. Science 132:676677

Simo R (2004) From cells to globe: approaching the dynamics of DMS(P) in the ocean at multiple scales. Can J Fish Aquat Sci 61:673-684

Simo R, Archer SD, Pedros-Alio C, Gilpin L, Stelfox-Widdicombe CE (2002) Coupled dynamics of dimethylsulfoniopropionate and dimethylsulfide cycling and the microbial food web in surface waters of the North Atlantic. Limnol Oceanogr 47:53-61

Simo R, Dachs J (2002) Global ocean emission of dimethylsulfide predicted from biogeophysical data. Global Biogeochem. Cycles 16:Article no. 1078

Simo R, Hatton AD, Malin G, Liss PS (1998) Particulate dimethyl sulphoxide in seawater: production by microplankton. Mar Ecol Prog Ser 167:291-296

Simo R, Pedros-Alio C (1999a) Role of vertical mixing in controlling the oceanic production of dimethyl sulphide. Nature 402:396-399

Simo R, Pedros-Alio C (1999b) Short-term variability in the open ocean cycle of dimethylsulfide. Global Biogeochem Cycles 13:1173-1181 
Simo R, Vila-Costa M (2006) Ubiquity of algal dimethylsulfoxide in the surface ocean: Geographic and temporal distribution patterns. Mar Chem 100:136-146

Slezak D, Herndl GJ (2003) Effects of ultraviolet and visible radiation on the cellular concentrations of dimethylsulfoniopropionate (DMSP) in Emiliania huxleyi (strain L). Mar Ecol Prog Ser 246:61-71

Slezak DM, Puskaric S, Herndl GJ (1994) Potential role of acrylic acid in bacterioplankton communities in the sea. Mar Ecol Prog Ser 105:191-197

Spiro PA, Jacob DJ, Logan JA (1992) Global inventory of sulfur emissions with $1^{\circ} \times 1^{\circ}$ resolution. J Geophys Res 97:6023-6036

Stefels J (2000) Physiological aspects of the production and conversion of DMSP in marine algae and higher plants. J Sea Res 43:183-197

Stefels J, Dijkhuizen L (1996) Characteristics of DMSP-lyase in Phaeocystis sp (Prymnesiophyceae). Mar Ecol Prog Ser 131:307-313

Stefels J, Dijkhuizen L, Gieskes WWC (1995) DMSP-lyase activity in a spring phytoplankton bloom off the Dutch coast, related to Phaeocystis sp. abundance. Mar Ecol Prog Ser 123:235-243

Stefels J, van Boekel WHM (1993) Production of DMS from dissolved DMSP in axenic cultures of the marine phytoplankton species Phaeocystis sp. Mar Ecol Prog Ser 97:11-18

Stefels J, van Leeuwe MA (1998) Effects of iron and light stress on the biochemical composition of Antarctic Phaeocystis sp. (Prymnesiophyceae). I. Intracellular DMSP concentrations. J Phycol 34:486-495

Steinke M, Daniel C, Kirst GO (1996) DMSP lyase in marine macro- and microalgae: intraspecific differences in cleavage activity. In: Kiene RP, Visscher PT, Keller MD, Kirst GO (eds) Biological and environmental chemistry of DMSP and related sulfonium compounds. Plenum Press, New York, pp 317-324

Steinke M, Malin G, Archer SD, Burkill PH, Liss PS (2002a) DMS production in a coccolithophorid bloom: evidence for the importance of dinoflagellate DMSP lyases. Aquat Microb Ecol 26:259-270

Steinke M, Malin G, Gibb SW, Burkill PH (2002b) Vertical and temporal variability of DMSP lyase activity in a coccolithophorid bloom in the northern North Sea. DeepSea Res Part II 49:3001-3016

Steinke M, Wolfe GV, Kirst GO (1998) Partial characterisation of dimethylsulfoniopropionate (DMSP) lyase isozymes in 6 strains of Emiliania huxleyi. Mar Ecol Prog Ser 175:215-225

Strom S, Wolfe G, Holmes J, Stecher H, Shimeneck C, Lambert S, Moreno E (2003a) Chemical defense in the microplankton I: Feeding and growth rates of heterotrophic protists on the DMS-producing phytoplankter Emiliania huxleyi. Limnol Oceanogr 48:217-229

Strom S, Wolfe G, Slajer A, Lambert S, Clough J (2003b) Chemical defense in the microplankton II: Inhibition of protist feeding by beta-dimethylsulfoniopropionate (DMSP). Limnol Oceanogr 48:230-237

Summers PS, Nolte KD, Cooper AJL, Borgeas H, Leustek T, Rhodes D, Hanson AD (1998) Identification and stereospecificity of the first three enzymes of 3-dimethylsulfo- niopropionate biosynthesis in a chlorophyte alga. Plant Physiol 116:369-378

Sunda W, Kieber DJ, Kiene RP, Huntsman S (2002) An antioxidant function for DMSP and DMS in marine algae. Nature 418:317-320

Tang KW, Dam HG, Visscher PT, Fenn TD (1999) Dimethylsulfoniopropionate (DMSP) in marine copepods and its relation with diets and salinity. Mar Ecol Prog Ser 179:71-79

Tang KW, Simo R (2003) Trophic uptake and transfer of DMSP in simple planktonic food chains. Aquat Microb Ecol 31:193-202

Toole DA, Kieber DJ, Kiene RP, Siegel DA, Nelson NB (2003) Photolysis and the dimethylsulfide (DMS) summer paradox in the Sargasso Sea. Limnol Oceanogr 48:1088-1100

Toole DA, Kieber DJ, Kiene RP, White EM, Bisgrove J, del Valle DA, Slezak D (2004) High dimethylsulfide photolysis rates in nitrate-rich Antarctic waters. Geophys Res Lett 31:Article no. L11307

Toole DA, Siegel DA (2004) Light-driven cycling of dimethylsulfide (DMS) in the Sargasso Sea: Closing the loop. Geophys Res Lett 31:Article no. L09308

Toole DA, Slezak D, Kiene RP, Kieber DJ, Siegel DA (2006) Effects of solar radiation on dimethylsulfide cycling in the western Atlantic Ocean. Deep-Sea Res Part I 53:136-153

Trossat C, Nolte KD, Hanson AD (1996) Evidence that the pathway of dimethylsulfoniopropionate biosynthesis begins in the cytosol and ends in the chloroplast. Plant Physiology 111:965-973

Turner SM, Bakker DCE, Goldson LE, Messias M-J, Nightingale PD, Riebesell $\mathrm{U}$ (in prep) Considerations on the use of sulfur hexafluoride as a deliberate tracer in oceanic biogeochemical lagrangian studies: lessons from EisenEx

Turner SM, Malin G, Liss PS, Harbour DS, Holligan PM (1988) The seasonal variation of dimethylsulfoniopropionate concentrations in near-shore waters. Limnol Oceanogr 33:364-375

Turner SM, Malin G, Nightingale PD, Liss PS (1996) Seasonal variation of dimethyl sulphide in the North Sea and an assessment of fluxes to the atmosphere. Mar Chem 54:245-262

Turner SM, Nightingale PD, Broadgate W, Liss PS (1995) The Distribution of Dimethyl Sulfide and Dimethylsulphoniopropionate in Antarctic Waters and Sea-Ice. Deep-Sea Res Part II 42:1059-1080

van Bergeijk SA, Schonefeldt K, Stal LJ, Huisman J (2002) Production and consumption of dimethylsulfide (DMS) and dimethylsulfoniopropionate (DMSP) in a diatom-dominated intertidal sediment. Mar Ecol Prog Ser 231:37-46

van den Berg AJ, Turner SM, van Duyl FC, Ruardij P (1996) Model structure and analysis of dimethylsulphide (DMS) production in the southern North Sea, considering phytoplankton dimethylsulphoniopropionate- (DMSP) lyase and eutrophication effects. Mar Ecol Prog Ser 145:233244

van Duyl FC, Gieskes WWC, Kop AJ, Lewis WE (1998) Biological control of short-term variations in the concentration of DMSP and DMS during a Phaeocystis spring bloom. J Sea Res 40:221-231

van Rijssel M, Buma AGJ (2002) UV radiation induced stress does not affect DMSP synthesis in the marine prymne- 
siophyte Emiliania huxleyi. Aquat Microb Ecol 28:167174

van Rijssel M, Gieskes WWC (2002) Temperature, light, and the dimethylsulfoniopropionate (DMSP) content of Emiliania huxleyi (Prymnesiophyceae). J Sea Res 48:1727

Vezina AF (2004) Ecosystem modelling of the cycling of marine dimethylsulfide: a review of current approaches and of the potential for extrapolation to global scales. Can J Fish Aquat Sci 61:845-856

Ward B, Wanninkhof R, McGillis WR, Jessup AT, DeGrandpre MD, Hare JE, Edson JB (2004) Biases in the air-sea flux of $\mathrm{CO}_{2}$ resulting from ocean surface temperature gradients. J Geophys Res-Oceans 109:Article no. C08S08

Wilson WH, Schroeder DC, Allen MJ, Holden MTG, Parkhill J, Barrell BG, Churcher C, Harnlin N, Mungall K, Norbertczak H, Quail MA, Price C, Rabbinowitsch E, Walker D, Craigon M, Roy D, Ghazal P (2005) Complete genome sequence and lytic phase transcription profile of a Coccolithovirus. Science 309:1090-1092

Wilson WH, Tarran G, Zubkov MV (2002) Virus dynamics in a coccolithophore-dominated bloom in the North Sea. Deep-Sea Res Part II 49:2951-2963

Wilson WH, Turner S, Mann NH (1998) Population dynamics of phytoplankton and viruses in a phosphate-limited mesocosm and their effect on DMSP and DMS production. Estuar Coast Shelf Sci 46:49-59

Wolfe GV (2000) The chemical defense ecology of marine unicellular plankton: Constraints, mechanisms, and impacts. Biol Bull 198:225-244

Wolfe GV, Levasseur M, Cantin G, Michaud S (2000) DMSP and DMS dynamics and microzooplankton grazing in the Labrador Sea: application of the dilution technique. DeepSea Res Part I 47:2243-2264

Wolfe GV, Steinke M (1996) Grazing-activated production of dimethyl sulfide (DMS) by two clones of Emiliania huxleyi. Limnol Oceanogr 41:1151-1160
Wolfe GV, Steinke M, Kirst GO (1997) Grazing-activated chemical defence in a unicellular marine alga. Nature 387:894-897

Wolfe GV, Strom SL, Holmes JL, Radzio T, Olson MB (2002) Dimethylsulfoniopropionate cleavage by marine phytoplankton in response to mechanical, chemical, or dark stress. J Phycol 38:948-960

Yang GP, Tsunogai S (2005) Biogeochemistry of dimethylsulfide (DMS) and dimethylsulfoniopropionate (DMSP) in the surface microlayer of the western North Pacific. DeepSea Res Part I 52:553-567

Yang H, McTaggart AR, Davidson AT, Burton H (1994) Measurement of acrylic acid and dimethyl sulfide in Antarctic coastal water during a summer bloom of Phaeocystis pouchetii. the NIPR Symposium on Polar Biology, no. 7. National Institute of Polar Research, Tokyo, pp 4352

Yoch DC (2002) Dimethylsulfoniopropionate: Its sources, role in the marine food web, and biological degradation to dimethylsulfide. Appl Environ Microbiol 68:5804-5815

Zemmelink HJ, Gieskes WWC, Klaassen W, Beukema WJ, de Groot HW, de Baar HJW, Hintsa EJ, McGillis WR, Dacey JWH (2004) Relaxed eddy accumulation measurements of the sea-to-air transfer of dimethylsulfide over the northeastern Pacific. J Geophys Res-Oceans 109: C01025, doi: 1029/2002JC001616

Zubkov MV, Fuchs BM, Archer SD, Kiene RP, Amann R, Burkill PH (2001) Linking the composition of bacterioplankton to rapid turnover of dissolved dimethylsulphoniopropionate in an algal bloom in the North Sea. Environ Microb 3:304-311

Zubkov MV, Fuchs BM, Archer SD, Kiene RP, Amann R, Burkill PH (2002) Rapid turnover of dissolved DMS and DMSP by defined bacterioplankton communities in the stratified euphotic zone of the North Sea. Deep-Sea Res Part II 49:3017-3038 